\title{
norden
}

Nordic Council of Ministers

Ved Stranden 18

DK-1061 Copenhagen K

www.norden.org

NORDISKE ARBEJDSPAPIRER

NORDIC WORKING PAPER

\section{Reform of Fossil-fuel Subsidies}

Nordic Cooperation on fossil-fuel subsidy reform in developing countries: Assessing Options and Opportunities

Laura Merrill

http://dx.doi.org/10.6027/NA2014-903

NA2014:903

This working paper has been published with financial support from the Nordic Council of Ministers. However, the contents of this working paper do not necessarily reflect the views, policies or recommendations of the Nordic Council of Ministers. 



\section{Content}

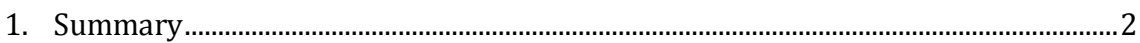

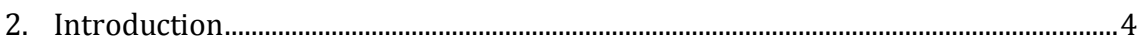

3. Fossil-fuel subsidies and sustainable development......................................................

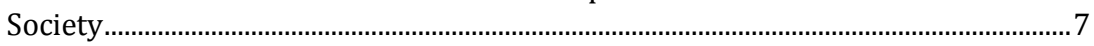

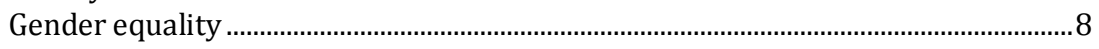

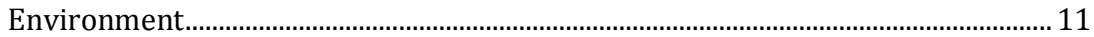

Citizens and governments ....................................................................................... 13

4. Current Nordic support towards Fossil-fuel Subsidy Reform ................................. 15

International Development Assistance..................................................................... 15

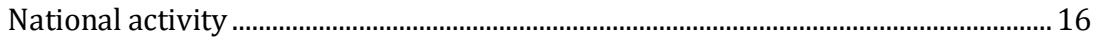

5. Nordic sustainable development initiatives and programmes ................................. 19

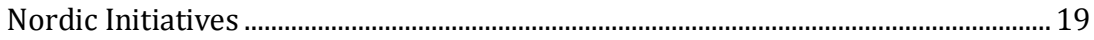

Nordic Country Initiatives ........................................................................................ 20

Opportunities for collaboration............................................................................... 21

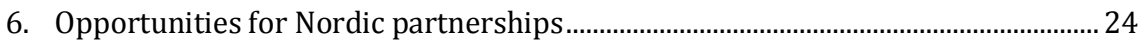

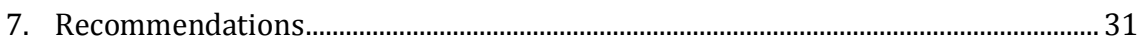

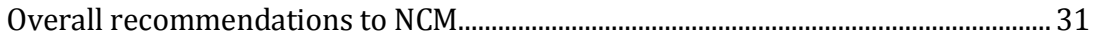

7.1 Supporting Reform with Carbon Mitigation Benefits....................................... 32

7.2 Energy Subsidy Management Network ............................................................. 33

7.3 Supporting Reform with Social Safety Nets ..................................................... 35

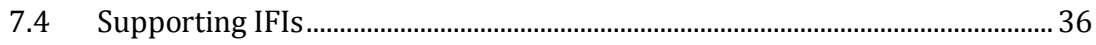

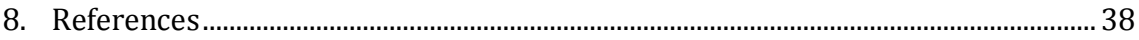

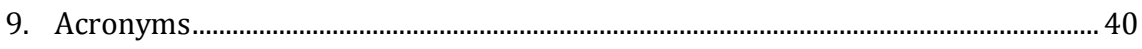

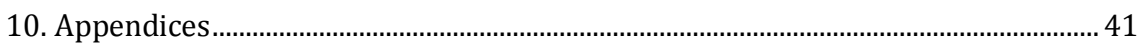

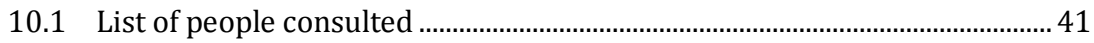

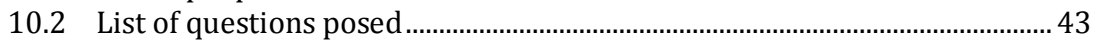

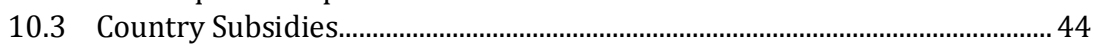




\section{Summary}

Fossil-fuel subsidies matter. They matter for sustainable development; they matter for government budgets; they matter for the poor who benefit very little; they matter for women and accessing daily necessities such as heating, lighting, cooking and transport; and they matter for the environment in that they work in the opposite direction of a low-carbon future, impede renewable take-off, stifle energy efficiency and dwarf climate finance. And fossil-fuel subsidies are big. Government support to fossil-fuel subsidies is between $\$ 45$ and $\$ 75$ billion annually for OECD countries. Globally, subsidies increased to around $\$ 544$ billion in 2012 and are a significant proportion of some developing country government budgets. Reforming and redirecting fossil-fuel subsidies will be an important piece of the jigsaw if we are to solve the climate change puzzle in absolute reductions in emissions, in 'getting the prices right' so that renewables can compete, and in order for energy efficiency measures to be economically worthwhile. Savings can enable governments to manage deficits; could be redirected towards building sustainable energy networks; or targeted at social spending on health, education or safety nets. This paper finds many opportunities for Nordic countries to increase cooperation around fossil-fuel subsidy reform. There are a number of existing vehicles through which work streams could be developed including the NDF and the NEFCO. Nordic countries have led the way with membership of the Friends of Fossil-fuel Subsidy Reform group, commitments on peer review and funding to specific initiatives on fossil-fuel subsidy reform such as the IISD's Global Subsidies Initiative and ESMAP. Specific country initiatives such as Energy+ and 3GF hold promise for action on the ground, and efforts to build Nordic NAMAs with partner countries such as Vietnam and Peru could be models for future action for the energy sector in general. Other models such as OFD and the EITI are important for developing workable processes that enable country ownership of transparency around resource use, and that are replicable and scalable.

Fossil-fuel subsidies are most intense in the MENA countries and Souteast Asia, but are prevalent in other regions as well. Potential partner countries (based on Nordic IDA priorities and subsidies) include: Ghana, Ethiopia, Indonesia, Myanmar, Sri Lanka, Bangladesh, Vietnam, India, Bhutan, Pakistan, Sudan, Kyrgyz Republic and Bolivia. The GSI makes the following set of recommendations for Nordic work around fossil-fuel subsidy reform and proposes that recommendations 1 and 2 
have the best fit with the remit of the NCM, although all would fit with moving fossil-fuel subsidy reform forwards.

\section{Supporting Reform with Benefits from Carbon Mitigation}

Benefits: Nordic countries could seek to support partner countries undertaking fossil-fuel subsidy reform through purchasing carbon mitigation credits stemming from reform and through financial support to countries for reform and low-carbon energy investment.

2. Energy Subsidy Management Network: Nordic countries could develop the potential for an energy subsidy network of excellence that is demand driven, responding to the needs of countries to accelerate the pace of fossil-fuel subsidy reform in both developed and developing countries, providing both information and technical assistance.

3. Supporting Reform with Social Safety Nets: Nordic countries could partner with countries undertaking fossil-fuel subsidy reform with support for mitigation or flanking mechanisms around the process of reform, alongside the development of social safety nets aimed at the poor.

4. Supporting IFIs: Nordic countries could seek to support multi-lateral International Financial Institutions to develop policies and programmes enabling countries to phase out fossil-fuel subsides and ensure reforms are enacted in a way that manages social impacts as far as possible. 


\section{Introduction}

In 2010 Nordic Prime Ministers agreed that the Nordic Working Group on Green Growth should identify:

- Areas and sectors within green growth in which a joint approach would be capable of generating Nordic synergies, and which would have the potential to constitute priorities for Nordic co-operation on globalisation

- 2-3 tangible green growth initiatives capable of generating shortterm results (low-hanging fruits), including via closer co-ordination and pooling national endeavours

- 2-3 joint strategies priorities with long-term perspectives

- Opportunities for linking Nordic green-growth activities with existing national, European and global measures, as well as with funding sources

In 2011 a report was published by the Nordic prime ministers' Working Group for Green Growth that highlighted eight priorities including "promoting the integration of the environmental and climate considerations into development aid." It was observed Nordic countries have '... incorporated environmental and/or climate targets and priorities into their development aid programmes, but more could be done to integrate environmental aspects into aid ...' and furthermore that a "joint approach by the effective Nordic development aid bodies, preferably coordinated with other stakeholders, especially in the private sector, has the potential to promote greater emphasis on green criteria in international development aid and make an impact on the global environment." The report also recognised existing collaboration around aid via the Nordic Development Fund (NDF), the Nordic Environment Finance Corporation (NEFCO) and the Nordic Climate Facility (NCF).

In 2012 The Nordic Council of Ministers (NCM) published the Nordic Environmental Action Plan 2013-2018 covering four main areas of action namely: inclusive green development, climate change and air pollution, biological diversity and ecosystems, and chemicals with adverse impacts. One way to meet the objective of reducing "emissions of greenhouse gases and air pollutants in order to avoid serious climate change, thereby sticking to the target of restricting global warming to below 2 degrees Celsius and limiting negative environmental and human health effects" is that "The Nordic countries will work to phase out subsidies to fossil-fuels and introduce taxes that reflect environmental impact. This will 
provide the right incentives to reduce emissions from energy and transport, including international shipping and aviation. The Nordic countries will seek sustainable solutions to the production and use of biofuels, while ensuring that this does not displace food production." NCM (2012).

This research project, undertaken for the NCM by the Global Subsides Initiative (GSI) of the International Institute for Sustainable Development (IISD), seeks to undertake the following:

"identify options and opportunities for increased Nordic cooperation on phasing out fossil-fuel subsidies in developing countries. The project will produce a study that will:

- Propose areas of activity in which cooperation could be enhanced, including technical assistance, inter-governmental dialogue, and cooperation amongst civil society organisations;

- Suggest partners in developing countries;

- Identify options for better aligning fossil-fuel subsidy reform to other Nordic priority issues, including climate change, poverty alleviation and gender equity;

- Identify complementary initiatives in international fora, such as the UNFCCC climate change negotiations (i.e. discussing how fossil-fuel subsidy reform could be supported as NAMAs);

- Propose an initial set of activities that could be implemented in 2014 as a pilot program.

- The study would be presented and discussed to the Nordic Council of Ministers at a workshop in early 2014."

This report draws on some 30 meetings that took place with government officials and those working on sustainable development across the Nordic countries between December 2013 and January 2014. Those people involved and their organizations are listed in the appendix.

This report is organized in the following way:

- first, a section providing a very brief overview of the impacts and implications of fossil-fuel subsidies for sustainable development;

- second, a description of current Nordic support and leadership towards the issue of fossil-fuel subsidy reform;

- third, Nordic initiatives that are indirectly linked to fossil-fuel subsidy reform or with the potential for linkage in the future;

- fourth, an outline of opportunities for Nordic collaboration for both technical work and from a global policy dimension;

- fifth, a section mapping Nordic development priorities and countries with high fossil-fuel subsidies; and

- finally, four specific recommendations to the Nordic Council of Ministers for potential ways forward. 
This report is as a result of those discussions and wider information surrounding fossil-fuel subsidy reform. It does not go into the problem itself in depth but rather looks towards the future at what is needed to scale-up work around fossil-fuel subsidy reform and how Nordic support, cooperation and collaboration could enable this. 


\section{Fossil-fuel subsidies and sustainable development}

Fossil-fuel subsidies matter. They matter for sustainable development; they matter for government budgets; they matter for the poor who benefit very little; they matter for women and accessing daily necessities such as heating, lighting, cooking and transport; and they matter for the environment in that they work in the opposite direction of a low-carbon future, impede renewable take-off, stifle energy efficiency and dwarf climate finance. And fossil-fuel subsidies are big. OECD government producer and consumer support for fossil-fuels is between USD 45 to 75 billion annually (OECD, 2011). In developing countries subsidies are a significant proportion of government budgets. Globally, energy subsidies totalled around $\$ 544$ billion in 2012 (IEA, 2013). This section looks briefly at why fossil-fuel subsidies matter to the poor, to women, to the environment, to government budgets and to lost opportunities for social investment.

\section{Society}

Who benefits from fossil-fuel subsidies? In developing countries the rich tend to benefit disproportionally from fossil-fuel subsidies. Research has found that "over 97 out of every 100 dollars of gasoline subsidy "leaks" to the top four quintiles" and that "on average, the top income quintile received about six times more in subsidies that the bottom quintile" (Arze del Granado et al., 2010). This International Monetary Fund (IMF) research reviewed 20 countries and examined the direct impacts of increasing prices on cooking, heating, lighting and private transport fuels, and the indirect impacts on other goods and services such as public transport or food requiring a higher energy input. Increasing prices for gasoline and electricity have a strongly progressive impact, but the same is not true for kerosene which is strongly regressive. Yet low kerosene prices result in substitution of kerosene for diesel leading to shortages and smuggling to other countries. Welfare distributions for increasing prices in Liquefied Petroleum Gas (LPG) differ across regions, on average progressive, but regressive in the Middle East and Central Asia. Overall, the study found that an increase in prices has a negative impact on welfare, although the decrease in welfare is approximately neutral across income groups (changes in kerosene prices have a significant 
welfare impact on the poor). There is substantial leakage of subsidy benefits to top income groups implying that "universal fuel subsidies are extremely costly approach to protecting the welfare of poor households," investment of resources into safety nets being far more efficient at reaching the poor than fuel subsidies. The International Energy Agency (IEA) also found that although fossil-fuel subsidies are intended to improve access to modern energy services for the poor, only $8 \%$ of the subsidy granted typically reaches the poorest income group (IEA, 2011).

\section{Figure 1: Distribution of subsidy benefits by social group, \%}

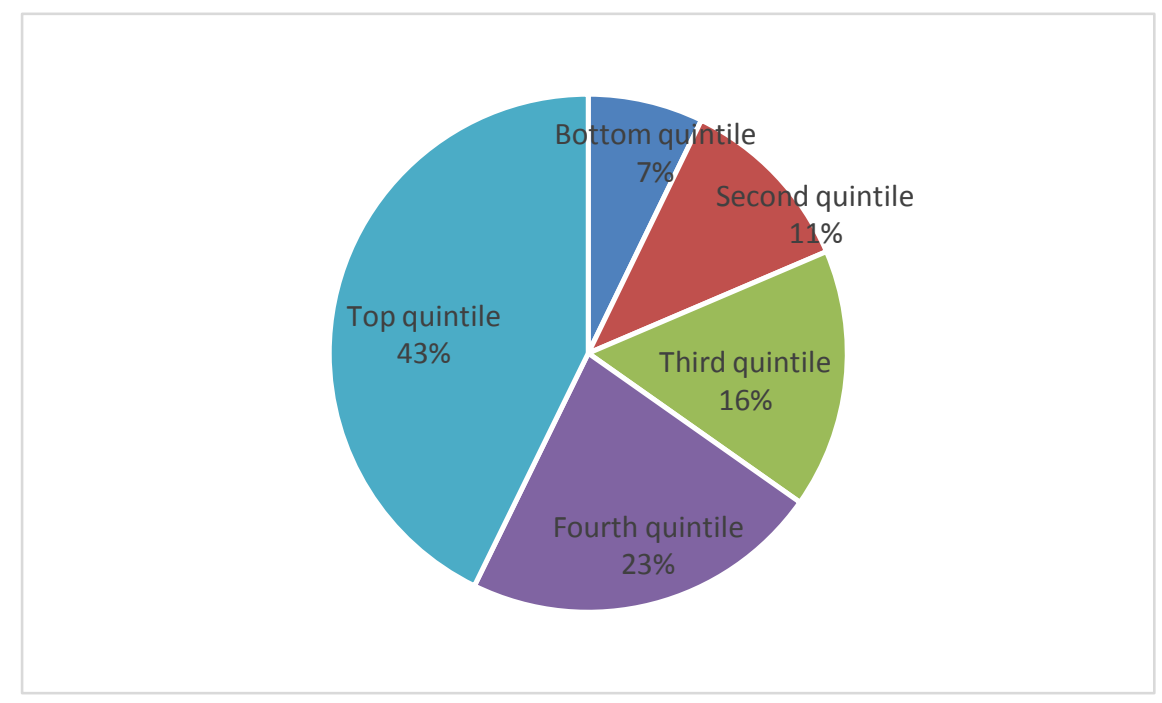

Source: Based on Arze del Granado, Coady, and Gillingham, 2010

\section{Gender equality}

\section{Box 1: Gender impacts and fossil-fuel subsidy reform}

Women and men, rich and poor, rural and urban, young and old are affected in different ways by increasing fuel prices. In order to fully understand and anticipate impacts much depends on detailed, sound and regular data from household surveys, particularly information that is broken down by gender groups to provide baseline data in order to understand the impacts of policy changes. Immediate impacts from reform that are likely to impact on gender equality could include increased costs to households in cooking, lighting and heating fuels. These immediate impacts can be high especially where a large percentage of household income is spent on energy costs. Secondary impacts may include increasing prices in public transportation and costs of transporting goods to market. Arze del Granado et al. (2010) found that a \$0.25 decrease in the per liter subsidy results in a $5 \%$ decrease in income for all groups. Half of this 
impact comes from indirect impacts due to higher fuel prices on other goods and services used by households. Understanding and mitigating the impact of reform on vulnerable households and women is important.

Cooking fuel: Around $38 \%$ of the world's population (2.6 billion people) cook with open fires and stoves that burn biomass (wood, charcoal, dung and crop waste) and coal (IEA 2013), a quarter of whom live in Africa. The World Bank report that 'every year fumes and smoke from open cooking fires kill approximately 1.5 million people mostly women and children, from emphysema and other respiratory diseases.'(The World Bank, 2014a) In Orissa, India, research (Duflo et al. 2008) found that indoor air pollution shows a significant health threat in rural households where households rely on traditional stoves for cooking, with one third of adults and half of all children experiencing symptoms of respiratory illness over the survey period. The study found a strong correlation between using a stove with cleaner fuels and having better respiratory health, but the findings also pointed other factors that could matter such as empowerment of women and income levels. Globally, women exposed to heavy indoor smoke are three times more likely to suffer from chronic bronchitis than women using cleaner fuels. Almost half of deaths amongst children under five from acute lower respiratory infections are due to indoor air pollution from household solid fuels (WHO, 2009).

Lighting: $18 \%$ of the world's population (1.3 billion people) lack electricity (IEA, 2013). Sub-Saharan Africa and developing Asia account for $95 \%$ of the global total. Those without electricity are using other sources for lighting, like kerosene, which can also have health impacts and risks such as from burns and other injuries. A quarter of those people without access to electricity live in India, the largest population without access to electricity anywhere on the globe at around 400 million (The World Bank, 2014a). A lack of access to electricity impacts on women in many ways from poor clinics and health care facilities, to lack of refrigeration to keep food and medicines fresh, to restrictions on educational and economic activities due to lack of lighting and power. Around the globe different fuels affect household health in different ways, so fuel switching can make a big difference either positively for health or in the opposite direction. Switching to cleaner cooking fuels such as kerosene, liquid petroleum gas (LPG) or biogas would save many lives and reduce suffering linked to indoor air pollution and hours spent searching for firewood. Access to electricity could have further life changing impacts for women also.

Potential impacts on fossil-fuel subsidy reform on women: If a country's policy has been to decrease the cost of cleaner fuels (which has been the case in India with both LPG and kerosene) via generous subsidies to increase uptake, then it is important to look carefully at the gender im- 
pacts of removing subsidies, and subsequent price increases on women across income brackets. But it is also important to look at the impact that subsidies have had at achieving their stated policy objectives. Some in India argue that even with high subsidies the take-up of cleaner cooking fuels has been very slow and therefore inefficient. This is due to a whole host of reasons including poverty, rural access, and the low opportunity cost of time associated with women collecting wood and dung. Importantly, household decisions over cooking fuels are not just linked to price but also to empowerment of women and having a say in the choice of household fuel use (Kishore, 2013). The GSI has undertaken research into gender impacts of fossil-fuel subsidy reform in India (forthcoming) and finds that far more work needs to be undertaken to understand the impacts of reform on gender. Household surveys, can reveal a great deal of information around fuel switching and household expenditure but often information may not be specific enough to understand gender impacts of reform.

Energy: It is recognised that not only must gender dimensions be included within thinking about impacts stemming from fossil-fuel subsidy reform, but also across the energy sector more broadly. ESMAP (Energy Sector Management Assistance Programme, a technical assistance programme administered by the World Bank) has online tools for gender and the energy sector and a four step process including: a gender assessment; an action plan; implementation and monitoring; and completion and evaluation. Through the Norwegian Action Plan for Women's Rights and Gender Equality efforts are being made to ensure that programmes such as Energy+ are gender sensitive. The UN Sustainable Energy for All (SE4ALL) initiative aims towards three goals: universal access to modern energy services; a doubling of the rate in improvement of energy efficiency; and a doubling in the share of renewable energy in the global energy mix. In general there is little targeting or linkage between overall energy policy and gender goals.

Social safety nets: In the case of universal subsidies that are 'untargeted' and often captured by the rich, it can be said that if policy priorities are aimed at reducing gender inequality then financing fossil-fuel subsidies are not the best way to deliver gender equitable outcomes. Rather, social safety nets (SSNs) can be targeted directly at poor women. For example a recent programme launched by the World Bank and UNICEF in 2013 will provide eligible women with $\$ 20$ a month for two years to invest in young children, between 2000 and 2010 the World Bank invested \$4.4 billion in 60 social protection projects across 23 sub-Saharan countries (The World Bank, 2014b). If India and other government policies are to encourage a move towards cleaner fuels and gender empowerment, it could be better achieved through targeting in-kind, cash and social safety nets at poor women combined with the desired positive energy out- 
comes, or to enable women to make such energy choices directly with their own cash.

\section{Environment}

The GSI have been tracking research into the environmental effects of fossil-fuel subsidy reform for a number of years. There are three reasons for reform from an environmental perspective: first, short-term direct emissions mitigation and reductions in greenhouse gases due to a decrease in consumption of fossil-fuels; second, a mid-term rebalancing of the current lop-sided nature of fossil-fuel subsidy support vis-a-vis climate finance; and third, the long-term impacts of 'getting the prices right' so that renewables can compete on a level playing field and with the real potential to flourish, alongside making energy efficiency measures economically worthwhile.

First, there is growing research, modelling and evidence to suggest that reforming fossil-fuel subsidies is an important piece of the jigsaw needed if we are to solve the climate change puzzle in terms of absolute reductions in greenhouse gas (GHG) emissions. The latest World Energy Outlook outlines four clear policies in the 4 -for $-2^{\circ} \mathrm{C}$ scenario entailing no net economic cost and aiming to move the world onto an emissions pathway that would "keep the door open to achieving the $2^{\circ} \mathrm{C}$ target." The report states that "policies were selected on the basis that they can deliver significant reductions in energy sector emissions by 2020 (as a bridge to further action), rely on existing technologies, have already been proven in several countries, and their implementation as a package would not harm economic growth in any region. The four policies are:

- Adopting specific energy efficiency measures (49\% of emissions savings)

- Limiting the construction and use of the least efficient coal-fired power plants (21\%)

- Minimising methane $\left(\mathrm{CH}_{4}\right)$ emissions from upstream oil and gas production (18\%)

- Accelerating the (partial) phase-out of subsidies to fossil-fuel consumption (12\%)."

The IEA (2013) state that "accelerated action towards a partial phase out of fossil-fuel subsidies would reduce $\mathrm{CO}_{2}$ emissions by $360 \mathrm{Mt}$ in 2020. Globally, fossil-fuel subsidies amount to $\$ 544$ billion in 2012, more than five times the level of support going to renewables." 
Figure 2: Change in world $\mathrm{CO}_{2}$ emissions through fossil-fuel subsidy reform in the 4-for- $2^{\circ} \mathrm{C}$ Scenario relative to the New Policies Scenario 2020

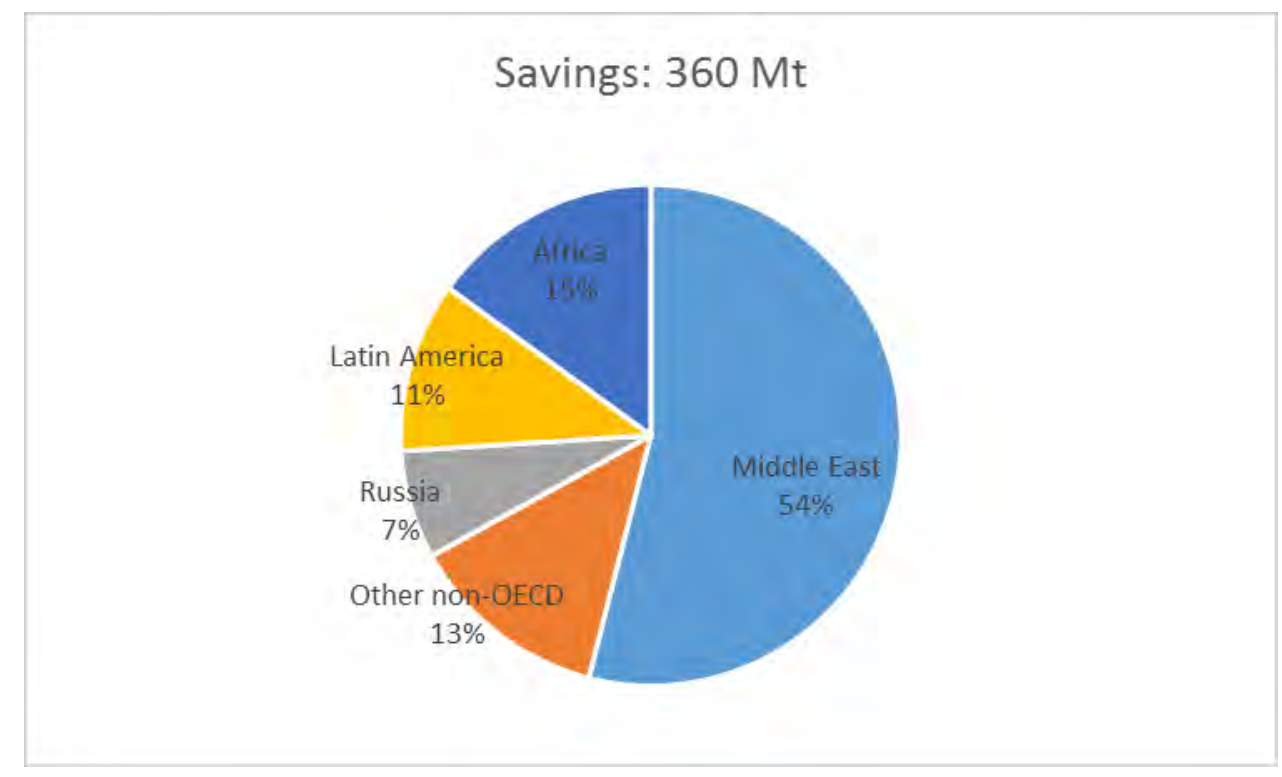

Source: IEA (2013)

Removal of 'post-tax subsidies' (in IMF's definition those subsidies to fossil-fuels that stem from inefficient taxation, namely a lack of inclusion of VAT and externalities such as the social cost of carbon and air pollution) could lead to a $13 \%$ decline in $\mathrm{CO}_{2}$ emissions (IMF, 2013). Post-tax subsidies equalled \$1.9 trillion in 2011 and are found in developed economies (40\%), with oil exporters accounting for about one third of subsidies.

As part of a series of reports, the GSI (2010) reviewed six major multicountry, multi-fuel studies undertaken since the early 1990s, each of which assessed the economic and environmental impacts of reform at a global level. All six of the major studies concluded that reform would lead to reductions in $\mathrm{CO}_{2}$ emissions, although predictions of the magnitude of reductions varied significantly, from $1.1 \%$ by 2010 to $18 \%$ by 2050. A study by Burniaux et al. (2009), concluded that, overall, world $\mathrm{CO}_{2}$ emissions would be reduced by $13 \%$ and GHG emissions would be reduced by $10 \%$ by 2050 if consumer subsidies for fossil-fuels and electricity in 20 non-OECD countries were phased out. Because all six studies estimated the current scale of fossil-fuel subsidies using a method that produces a conservative estimate, the 'price-gap approach' (Koplow, 2009), all are likely to have under-predicted the true scale of achievable reductions. Little work has been done to assess other environmental impacts, such as local air or water pollution, or demand for water or land. 
Second, fossil-fuel subsidies are dwarfing climate finance. Between 2010 and 2012 developed countries reported that they mobilised US\$ 35 billion for climate change (Nakhooda et al 2013). Yet, for the single year of 2011, the IMF estimated that pre-tax fossil-fuel subsidies amounted to $\$ 480$ billion. Notably, a recent review finds that the top 11 developed country emitters (E-11) ${ }^{1}$ invested twice as much in fossil-fuel projects as in clean energy projects through IFIs between 2008 and 2011 (Whitley, 2013).

Third, the energy playing field it is far from level. IEA (2013) finds that the $\$ 544$ billion of fossil-fuel subsidies in 2012 is around five times the level of total financial support to renewable energy ( $\$ 101$ billion). Around $15 \%$ of global $\mathrm{CO}_{2}$ emissions receive an incentive of $\$ 110$ per tonne in the form of fossil-fuel subsidies, with only $8 \%$ subject to carbon pricing. This matters because such subsidies are completely unbalanced, but also, and more importantly, because on a global scale low-carbon technologies and energy pathways will never be able to compete on price when pitched against such levels of entrenched and ongoing state support, even before the development of taxation systems based on externalities linked to carbon emissions.

\section{Citizens and governments}

Citizens and governments also lose out to fossil-fuel subsidies. The fiscal crisis has strengthened the case to find savings within government budgets. The G20 and Asia Pacific Economic Cooperation (APEC) member countries have committed to phasing out inefficient fossil-fuel subsidies. There are real short term incentives for doing so, and getting government budget deficits under control is an important factor. Figure 3 below from the GSI (2013) shows fossil-fuel subsidies as against budget deficits for a number of Southeast Asian countries. Government expenditure on fossil-fuel subsidies also represents huge lost opportunities to development, in terms of social spending for primary education, health care and other sectors of society.

${ }^{1}$ Australia, Canada, France, Germany, Japan, Italy, Poland, Russia, Spain, United Kingdom and United States. 
Figure 3: Energy Subsidy and Budgetary Deficit or Surplus as a Percentage of GDP, 2007-2010
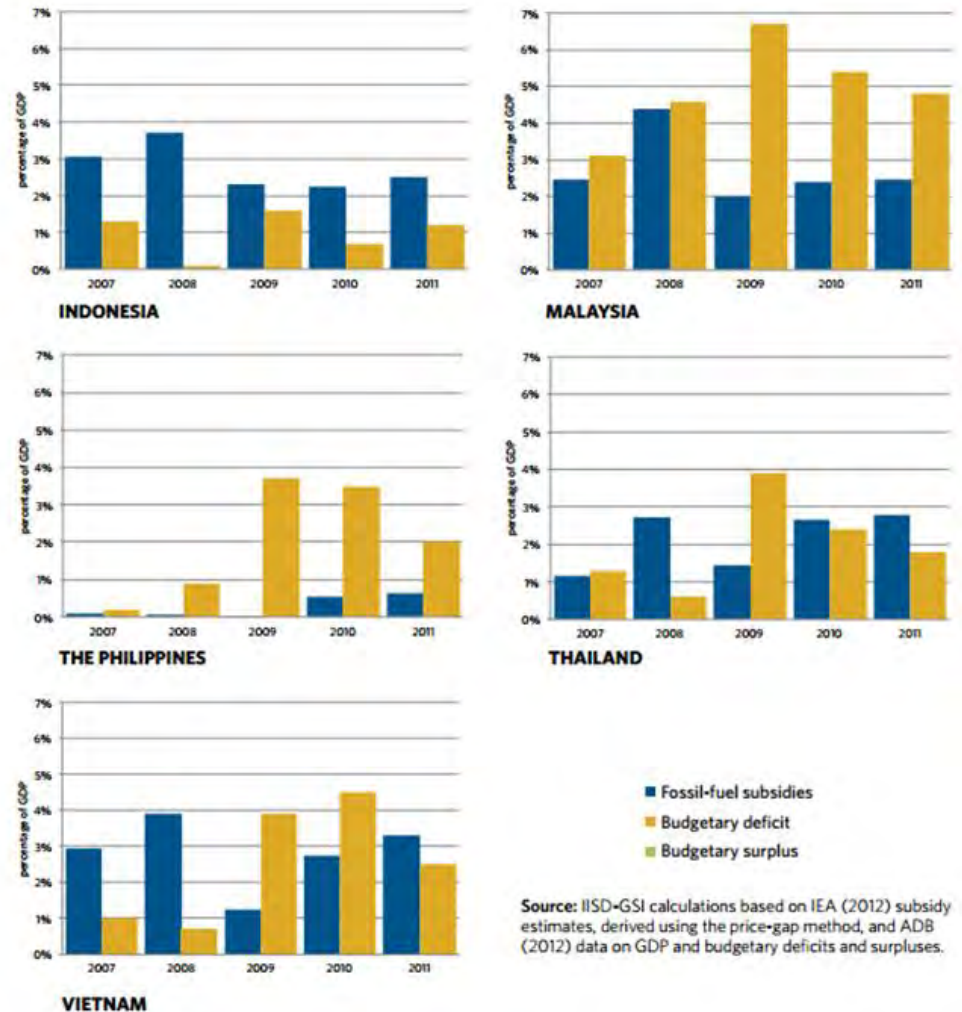

Source: GSI (2013)

Figure 4: Emerging and Developing Asia government spend on fossilfuel subsidies and health (\% of expenditure)

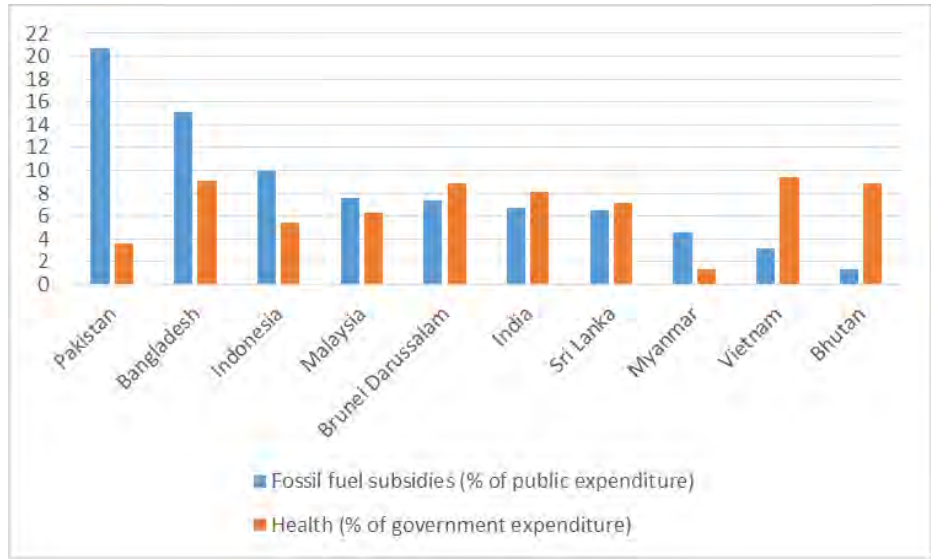

Source: WHO (2014), IEA (2013) and IMF (2013)

Notes: The GSI Subsidy database derived from IEA and IMF pre-tax subsidy data (2011). Fossil-fuel subsidy figures include data for petroleum products, gas and coal, where available. Susbidies towards electricity, which can also be very high, are not included. 


\section{Current Nordic support towards Fossil-fuel Subsidy Reform}

There are a number of activities in support of fossil-fuel subsidy reform that Nordic countries are currently engaged in from technical assistance to leadership.

\section{International Development Assistance}

A number of selected fossil-fuel subsidy reform activities are being supported through the World Bank, IEA and the GSI. The grouping includes a technical assistance facility within ESMAP (Energy Sector Management Assistance Program, The World Bank) to developing countries for planning and implementation of reforms of fossil-fuel subsidies (DKK 27.5 million, USD 5 million). The work is organised under the Energy Assessments and Strategy Program, entitled Energy Subsidy Reform and Delivery. ESMAP has been running since 1983 with overall support from most Nordic countries, although the specific energy subsidy reform section of ESMAP is relatively new, starting in 2013. This facility around fossil-fuel subsidy reform is also supported financially by the EU. There is also support to the development and dissemination by IEA of approaches to fossil-fuel subsidy reform through policy dialogues with partner countries (DKK 7.5 million, USD 1.4 million). It is expected that this work within the IEA will also be supplemented with a contribution from the EU. Finally, there is support for information towards, and involvement of civil society in reform efforts (India, Indonesia and Vietnam) and support for multilateral dialogue managed by the Global Subsidies Initiative of IISD (DKK 5 million). There is also more general IFI support including to the OECD who provide support around national inventories to members annually.

GSI 2012-2015 work program: Norway, Denmark and Sweden currently support the Global Subsidies Initiative's work with roughly equal funding for Phase 3 (April 2012- March 2015, total USD 4.25 million over 3 years). The overarching goal of GSI is to support the phase out of subsidies that undermine sustainable development. 
Box 2: The Global Subsidies Initiative The GSI's work program supports better subsidy policies across the energy field (including fossil-fuels, renewables, biofuels and nuclear). The GSI's work on fossil-fuel subsidy reform includes activities to support national reform on a generic level (such as identifying and disseminating international best practice), as well as a strong focus on a number of priority countries. Over the last years the GSI has been most active in Indonesia, India, Bangladesh, Vietnam, Egypt and Nigeria. The GSI have full-time staff working on fossil-fuel subsidy reform in Indonesia and India, and long-standing partnerships in all of the countries of operation. Partnerships with local institutions and experts is critical to analysis quality, influence and sustainability of the messages and activities. The GSI also devotes considerable attention to international fora and processes. This includes support to the Friends of Fossil-fuel Subsidy Reform, and activities aimed at progressing the issue within the G20, APEC, UNFCCC, and WTO.

The Nordic Development Fund, supported through the five Nordic countries, whilst not currently working directly on fossil-fuel subsidy reform, has a position paper on energy subsidies to guide grants in the energy sector. The position recognises that "public subsidies to fossilfuels should be discouraged" but that "subsidies can be extended to level the playing field for clean energy (like solar, wind and geothermal)" if this approach fits with country policies (NDF, 2010). Furthermore, the Nordic Council of Ministers commissioned and published extensive research in 2011, around the reform of environmentally harmful subsidies, including fossil-fuel subsidies (Bruvoll et al. 2011).

Box 3: Friends of Fossil-fuel Subsidy Reform Many Nordic countries are part of the Friends of Fossil-fuel Subsidy Reform group. Norway, Sweden, Finland and Denmark are all members, along with Costa Rica, Ethiopia, New Zealand, and Switzerland. The Friends group was formed in June 2010 to support G20 and APEC leaders' commitments to phase out inefficient fossil-fuel subsidies, to implement the initiative as soon as possible, with maximum ambition and transparency. Currently the Friends group meet around twice a year, and support research, events and statements around reform, such as the recent UNFCCC COP 19 side event on fossil-fuel subsidy reform and climate change. ${ }^{2}$

\section{National activity}

It is not within the scope of this report to look in detail at Nordic country research and positions around own subsidies, reform and management. 
However, it is an area to which there has been significant time and effort devoted to measuring, reporting, understanding and managing energy (and wider) subsidies vis-à-vis various government commitments and policy directions. Consumer subsidies of Nordic countries are reported by the OECD (which asks for country input) and IMF (which does not). Specific Nordic countries have assessed and reported on subsidies for national use along an inventory approach. Naturvårdsverket (The Swedish Environmental Protection Agency) reported in 2012 on subsidies (energy, transport and agriculture) with a potentially negative environmental impact, identifying those sectors in receipt of subsidies, and identifying progress made over time at reductions in subsidies following previous reports in 2004 and 2010. The aim was to provide detailed information in order to discuss how subsides can be better handled within policy instruments. The 2012 report clearly explains the problem of measurement of subsidies within a country with high tax levels (similar to that of other Nordic countries), in that subsidies calculated based on tax breaks appear much lower in countries with low tax regimes and higher in countries with high tax regimes. Therefore, comparison internationally is a challenge. Finland has also recently worked to assess subsidies in the energy, transport and agricultural sector using a traffic light approach to flag environmental harmful subsides.

\section{Box 4: Joint statement between the US and Nordic Countries}

The statement includes many areas of mutual interest but also a section on Fossilfuel Subsidy Reform. "As part of our commitment to accelerating the transition to lowcarbon energy systems worldwide, the leaders of Denmark, Finland, Iceland, Norway, and Sweden will join the United States in ending public financing for new coal-fired power plants overseas, except in rare circumstances. We will work together to secure the support of other countries and multilateral development banks to adopt similar policies. The Nordic countries and the United States agreed to continue their work, in all appropriate channels, to reduce the use of domestic fossil-fuel subsidies globally. The United States also agrees to join with the Nordic members of the Friends of Fossil-fuel Subsidy Reform to undertake peer reviews of domestic fossil-fuel subsidies." From the Joint Statement by Kingdom of Denmark, Republic of Finland, Republic of Iceland, Kingdom of Norway, Kingdom of Sweden, and the United States of America 04 September 2013

A process to review subsides across Nordic countries is indicated. Agreed guidelines on how to report on subsidies would be highly beneficial and this could work well given the similarity of Nordic countries. Measurement from a benchmark tax baseline or an optimal taxation rate could be possible given broad similarities in wealth, development and political outlook. This would enable governments to assess subsides provided to certain energy types over others using a similar methodology and approach within Nordics as a potential 'learning by doing' model from which G20 and other groupings could learn from. 
Intergovernmental organisations (IMF, WB, IEA and OECD) most active on subsidy reform support, and the GSI have convened three ad hoc meetings over the past 12 months to discuss collaboration and coordination of their work streams. This is expected to provide more detailed and consistence guidance as to how to identify and measure subsidies. Each organisation has a range of materials. The GSI has a number of publications linked to subsidies including a methodology which looks at measurement of subsidies using an inventory approach (being updated), a paper around how the peer-review process could work in practice (Gerasimchuk, 2013) and research into upstream or producer subsidies (including Canada, Russia, Norway and Indonesia) that generated both positive and negative comments and interest from the countries assessed. One way forward would be similar to OECD and UNFCCC review teams working on a national basis and then sharing reports amongst other countries for peer review.

As stressed above, it is not within the scope of this work to suggest work streams related to Nordic countries themselves, and yet there is a strong history within the Nordic Council of Ministers of working together on Nordic matters within and across the Nordic countries. There is the political will to work together (and now with the US) on this issue but action to move the process forward together is now needed. 


\section{Nordic sustainable development initiatives and programmes}

\section{Nordic Initiatives}

'Green Growth the Nordic Way' is the apt strapline to describe the pioneering initiatives and programmes exploring and mapping out green economic pathways across the Nordic countries, be that around welfare, energy, entrepreneurship, or the bio economy. Over the years a number of Nordic sustainability initiatives have developed linked indirectly to fossil-fuel subsidy reform, or provide potential models and ways of working around joint Nordic interests. Some, such as the Nordic Development Fund (NDF) and Nordic Environment Finance Corporation (NEFCO) are of particular interest to this research, as vehicles through which to distribute funds and to support in-country projects that could lead to both fossil-fuel subsidy reform and potential co-benefits such as carbon mitigation, better access to cleaner energy and building of social safety nets.

Table 1: Outline of roles of Nordic institutions linked to fossil-fuel subsidy reform

\begin{tabular}{|l|l|}
\hline Name & Description \\
\hline $\begin{array}{l}\text { The Nordic Development Fund } \\
\text { (NDF) }\end{array}$ & $\begin{array}{l}\text { NDF is the joint development finance institution of the Nordic countries. } \\
\text { NDF provides grant financing for climate change investments to the } \\
\text { poorest countries in the world. }\end{array}$ \\
\hline Norporation (NEFCO) & $\begin{array}{l}\text { NEFCO is a joint Nordic financial institution whose primarily purpose is to } \\
\text { generate positive environmental effects of interest to the Nordic region by } \\
\text { funding projects in Central and Eastern Europe countries. }\end{array}$ \\
\hline Nord-Star & $\begin{array}{l}\text { NCF finances projects that have a potential to combat climate change and } \\
\text { reduce poverty in low-income countries. The Facility is financed by the } \\
\text { NDF and administrated by NEFCO. There have been four calls for proposals } \\
\text { for grant financing for Nordic organisations with partners in eligible } \\
\text { developing countries. }\end{array}$ \\
\hline $\begin{array}{l}\text { Nordic Partnership Initiative } \\
\text { on Up-scaled Mitigation Action } \\
\text { (NPI) }\end{array}$ & $\begin{array}{l}\text { The Nordic Centre of Excellence for Strategic Adaptation Research, is } \\
\text { aimed at Nordic academic institutes working on and researching adapta- } \\
\text { tion within Nordic countries. }\end{array}$ \\
$\begin{array}{l}\text { The Nordic Partnership Initiative on Up-scaled Mitigation Action (NPI) is an } \\
\text { initiative between the Nordic Countries along with Peru and Vietnam. The } \\
\text { aim of the NPI is to demonstrate in practice how international climate } \\
\text { finance can be matched with up-scaled host country mitigation action } \\
\text { through two programmes. NPI explores partnerships between the devel- } \\
\text { oped and the developing world to bring down GHG emissions. }\end{array}$ \\
\hline Nordic Energy Research \\
$\begin{array}{l}\text { Nordic Energy Research is the funding institution for energy research } \\
\text { under the NCM. Work has looked at electric vehicles, and integration of } \\
\text { solar power technology, district heating and wind, as well as carbon } \\
\text { neutrality by 2050 for Nordic countries, some of which will require offsets. }\end{array}$ \\
\hline
\end{tabular}




\begin{tabular}{|l|l|}
\hline Nordic Innovation & $\begin{array}{l}\text { Nordic Innovation initiates and finances activities that enhance innovation } \\
\text { and co-operates primarily with small and medium sized companies in the } \\
\text { Nordic region. The mission is to make it easier to develop and do business } \\
\text { in the Nordic region without national barriers. There are a number of } \\
\text { lighthouse projects for example around green public procurement. }\end{array}$ \\
\hline MR-M & The Nordic Council of Ministers for the Environment \\
\hline EK-M & Nordic Committee of Senior Officials for Environmental Affairs. \\
\hline MEG & $\begin{array}{l}\text { Working group under the Nordic Committee of senior officials for the } \\
\text { Environment. }\end{array}$ \\
\hline NOAK & $\begin{array}{l}\text { The Working Group on Environment and Finance is a cross-sectoral group } \\
\text { whose mandate is approved by both the environment sector and the } \\
\text { finance sector of the Nordic Council of Ministers. The group's work relates } \\
\text { to relevant environmental economic matters of common Nordic interest. }\end{array}$ \\
\hline Working Group for Renewable & $\begin{array}{l}\text { The Nordic working group for global climate negotiations. The group's } \\
\text { overarching goal is to contribute to the adoption of a global climate } \\
\text { agreement with binding and ambitious goals. }\end{array}$ \\
$\begin{array}{l}\text { The Working Group for Renewable Energy is charged with helping and } \\
\text { supporting the Nordic countries' political and professional work in renew- } \\
\text { able energy by exchanging information and setting up co-operation } \\
\text { projects between the countries. In addition, the group will market Nordic } \\
\text { technology and know-how on renewable energy to neighbouring coun- } \\
\text { tries, to the EU and globally. }\end{array}$ \\
\hline
\end{tabular}

\section{Nordic Country Initiatives}

Specific Nordic country initiatives have the potential to link to fossil-fuel subsidy reform. Some countries have specific themed green growth and energy initiatives including 3GF (a Danish initiative) and Energy + (a Norwegian initiative with support from other Nordic countries). The Global Green Growth Forum (3GF) is a convening platform to bring governments, partners, investors and international organisations together around green growth. Governments such as Denmark, China, Kenya, Mexico, Qatar and the Republic of Korea are currently partners. The next 3G Forum is planned for the 20-21 October 2014 and there is the potential for a push around fossil-fuel subsidy reform at such a meeting. Energy+ (Norway, with Denmark and Sweden also participating) aims to focus on supporting the energy sector through increasing renewable energy, ensuring universal access to energy services and increasing the rate of energy efficiency. Activities are planned with Ethiopia, Liberia, Kenya, Bhutan, and Nepal. Countries are able to decide which instruments and incentives they will use to achieve results that they are then paid for. There have also been significant efforts to build nationally appropriate mitigation actions (NAMAs) between Nordic and partner countries through the Nordic Partnership Initiative (NPI) on up-scaled Mitigation Action with Nordic country support to Peru (waste sector) and to Vietnam (cement sector) to bring about GHG emission reductions. Financing has been organised through NDF, NEFCO, along with financing from partner governments (Vietnam). A number of partners and organisations have been involved in setting up such NAMAs, guided by the Nordic working group for global climate negotiations (NOAK). Finland has also built such NAMAs with Bangladesh (brick sector) and Thailand (renewable energy). 
There are other significant initiatives such as the Oil for Development Fund (OFD) of Norway, the largest provider of funds towards governance in the petroleum sector, now with 17 partner countries covering issues around resources, revenues, environment and safety in the petroleum sector and with funding of NOK 254 million in 2012. The Extractive Industries Transparency Initiative (EITI), with the Secretariat based in Oslo and significant support from Nordic countries, has around 41 countries engaged and around 800 people working together around transparency and governance issues within the extractives sector. Fossil-fuel subsidy reform links with the energy sector in many ways including the up-take of renewables, energy efficiency and links to the issue of universal access to modern fuels in terms of pricing and targeting of energy investments by governments (leap-frogging). Fossil-fuel subsidy reform also fits with within the Nordic approach to pricing environmental externalities in general, for example Norway recognises the principle of both the polluter pays and that of a positive carbon price (in that externalities must be factored into energy pricing), fossil-fuel subsidies work against 'getting the prices right' and against a carbon tax, but rather incentivise the use of carbon intensive fuels.

Designing an NCM project or programme that builds on other Nordic activities and expertise is key. Such Nordic efforts and pilot programmes themselves link to wider global ambitions such as agreement at the UNFCCC, UN Sustainable Energy for All (SE4All) or the development of Sustainable Development Goals (SDGs). Pilot projects are important for understanding what works and what doesn't, and for understanding how to arrange such cooperation in the future with more partners and on a bigger scale.

\section{Opportunities for collaboration}

The NDF has the potential to deliver support from Nordic countries to those other countries or institutions working on fossil-fuel subsidy reform in two major ways. First, regarding how current funds are directed. The NDF already has a clear policy on energy subsidies which outlines (amongst other things) that: "public subsidies to fossil-fuels should be discouraged. This would enhance energy efficiency and reduce global $\mathrm{CO}_{2}$ emissions. On the contrary, subsidies can be extended to level the playing field for clean energy (like solar, wind and geothermal) if this is in line with the policy of the country." This could be the basis for similar actions within other larger IFIs - especially given that some Nordic countries intend to make multilateral cooperation more efficient e.g. fewer and larger core contributions. NDF has strong links to other IFIs such as World Bank, the Asian Development Bank, the Inter-American Development Bank and the African Development Bank. Second, the NDF could be 
a channel for resources from Nordic countries directed at countries intending or delivering fossil-fuel subsidy reforms. The NDF's mission is to direct climate change funds to low income countries. NDF projects are organised in co-financing arrangements and this has been both alongside other Nordic donors (e.g. NAMAs work and Swedish funding) as well as partner countries (Vietnam), there could be a potential for match funding to be found from within recipient countries (resulting from savings made from reform). NEFCO currently supports projects in Central and Eastern Europe and more broadly across the globe through the Nordic Climate Facility. NEFCO could be a potential vehicle through which to support the development of sectoral change across a country's energy sector potentially involving both fossil-fuel subsidy reform alongside practical support towards energy efficiency and renewable energy. This could be organised (as with Peru and Vietnam) as NAMAs. NEFCO has also worked with the Norwegian government to deliver Certified Emissions Reductions through the Norwegian Carbon Procurement Facility. It is important to note the size of fossil-fuel subsidies in some countries within the Commonwealth of Independent States, and in Central and Eastern Europe (see appendix).

EITI, whilst a global initiative, is based in Norway with significant Nordic funding (alongside other donors such as the UK). EITI has had a leading role in transparency around the measurement of revenues to government from the extractive industries. Subsidies are often difficult to measure, not only because of a lack of agreement on how to do this, but also due to lack of transparency. There is potential to collaborate with others around transparency in the understanding and measurement of fossil-fuel subsidies. For example, this could be organized around an initial internal government, bottom-up, measurement of subsidies across EITI partner countries at varying stages of development which could be very useful to countries to see where resources are being allocated towards fossil-fuels, and where these could be reformed or redirected.

As noted, the Friends of Fossil-fuel Subsidy Reform group has been instrumental in bringing governments together on fossil-fuel subsidy reform and raising the profile of the issue globally, for example at the UNFCCC. Most Nordics are part of this informal grouping. Case studies from the efforts of the Friends group could be highlighted e.g. Norway and Ethiopia. The Friends have the opportunity to now lead by example with regard to peer-review (see box 4 with regard to the joint US-Nordic statement). Much internal work has already been achieved within Nordic countries around measurement of fossil-fuel subsidies and other subsidies harmful to the environment. Sharing of existing studies through the Nordic Council of Ministers or through the Friends group is one way forward, showing each other and others how governments 
tackle the measurement of subsidises, and how they highlight and manage important ones, could all be shared between governments for review and discussion. This process could then act as a template for other countries in the G20 and APEC to follow. Nordics could help G20 countries with their peer reviews, potentially developing a process that could support the US and China. 


\section{Opportunities for Nordic partnerships}

This section maps suggestions for potential partner countries based on Nordic priorities and fossil-fuel subsidies in order that a technical project be developed. Mapping was organised based on the following criteria:

- significant fossil-fuel subsidies,

- classification as a low income or lower-middle income economy, and

- an existing or potential focus from Nordic country IDA (Sweden, Finland, Denmark, Norway) and other institutions.

On the basis of this mapping the following potential partner countries were identified in Table 2 below.

Table 2: Potential partner countries

\begin{tabular}{|l|l|}
\hline SSA: & $\begin{array}{l}\text { (Cameroon), (Nigeria), Ghana, (Republic of Congo), An- } \\
\text { gola*, Ethiopia }\end{array}$ \\
\hline Asia: & $\begin{array}{l}\text { Indonesia, Vietnam, Myanmar, Sri Lanka, Bangladesh, } \\
\text { India, Bhutan, Pakistan, }\end{array}$ \\
\hline MENA: & (Egypt), (Yemen), Sudan, (Morocco) \\
\hline CEE-CIS: & Kyrgyz Republic \\
\hline LAC: & Bolivia \\
\hline
\end{tabular}

NB. Countries in brackets have significant subsidies (and are low income or lower middle income countries) but no identified match to Nordic countries current or potential IDA priorities. *Angola is classed as an upper-middle income country. Countries are in order of government subsidies to petroleum products, largest first.

However, this mapping assumes a demand driven interest from those countries identified and a bilateral approach. Table 3 below illustrates Nordic country, institutional and other organisational priorities with regard to broad development finance and effort. There are a few key trends. First, where IDA budgets are limited there is effort to focus funds on a few LDCs and phase out assistance to emerging economies. This is particularly the case for development assistance from Sweden where support is focused on twelve countries, and within which it is stated that Sweden will phase out long term cooperation with seven countries. A similar approach of focusing bilateral support to key long term partner countries is also the case for Finland and Denmark. Second, another trend appears to be a focus of greater funds with multi-lateral organisa- 
tions and IFIs. So, for example, Denmark plans fewer and larger investments in multilateral organisations and Finland has stated aims of focusing on multilateral organisations also. In 2012 48\% of Norway's IDA went to multilateral organisations such as the UN and the World Bank. The EU is also an important recipient of Nordic IDA. Third, countries like Norway have pushed new environmental and climate finance through efforts such as REDD+ (Reducing Emissions from Deforestation and Forest Degradation plus), enabling further support to be directed at countries such as Brazil. Climate finance, REDD+ finance and support towards fossil-fuel subsidy reform must be focused where it is really needed, even though these countries may not be LDCs. Furthermore, match funding can be provided to support governments in their allocation of resources. So whilst the OECD have asserted that development funds could be more focused, it is important to keep a broad perspective on where current sustainable development challenges must be met and these may well be in BRICS or emerging economies. 
Table 3: Mapping of Nordic IDA priorities and activity

\begin{tabular}{|c|c|}
\hline Initiative & Countries \\
\hline $\begin{array}{l}\text { NDF (Nordic) } \\
\text { (Eligible Coun- } \\
\text { tries) }\end{array}$ & $\begin{array}{l}\text { Africa: Benin, Burkina Faso, Cape Verde, Ethiopia, Ghana, Kenya, Malawi, Mozambique, } \\
\text { Rwanda, Senegal, Tanzania, Uganda, Zambia, Zimbabwe } \\
\text { Asia: Bangladesh, Cambodia, Kyrgyz Republic, Lao PDR, Maldives, Mongolia, Nepal, } \\
\text { Pakistan, Sri Lanka, Vietnam } \\
\text { Latin America: Bolivia, Honduras, Nicaragua }\end{array}$ \\
\hline NEFCO (Nordic) & $\begin{array}{l}\text { Russia, Ukraine, Estonia, Latvia, Lithuania, Moldova and Belarus as well as climate } \\
\text { projects across the world. }\end{array}$ \\
\hline EITI & $\begin{array}{l}\text { Albania, Azerbaijan, Burkina Faso, Cameroon, Central African Republic, Chad, Côte } \\
\text { d'Ivoire, Democratic Republic of Congo, Gabon, Ghana, Guatemala, Guinea, Indonesia, } \\
\text { Iraq, Kazakhstan, Kyrgyz Republic, Liberia, Madagascar, Mali, Mauritania, Mongolia, } \\
\text { Mozambique, Niger, Nigeria, Norway, Peru, Republic of the Congo, Sierra Leone, Tanza- } \\
\text { nia, Timor-Leste, Togo Trinidad and Tobago, Yemen, Zambia. }\end{array}$ \\
\hline GSI & $\begin{array}{l}\text { Bangladesh, Indonesia, Egypt, Thailand, Nigeria, India, Vietnam, Jordan, Tunisia, Moroc- } \\
\text { co and Libya. }\end{array}$ \\
\hline $\begin{array}{l}\text { Friends of Fossil- } \\
\text { fuel Subsidy } \\
\text { Reform group }\end{array}$ & $\begin{array}{l}\text { Members: Costa Rica, Ethiopia, New Zealand, Finland, Norway, Sweden, Denmark, } \\
\text { Switzerland. }\end{array}$ \\
\hline Energy + (Norway) & Ethiopia, Liberia, Kenya, Bhutan, and Nepal. \\
\hline 3GF (Denmark) & $\begin{array}{l}\text { Government partners: Denmark, China, Kenya, Mexico, Qatar, Rep of Korea along with } \\
\text { corporate and multilateral partners. }\end{array}$ \\
\hline NPI NAMA & Peru (waste) and Vietnam (construction) sectors \\
\hline $\begin{array}{l}\text { Oil For Develop- } \\
\text { ment (Norway) }\end{array}$ & $\begin{array}{l}\text { Partner countries (2013): Angola, Bolivia, Cuba, Ghana, Iraq, Ivory Coast, Lebanon, } \\
\text { Liberia, Mozambique, Nicaragua, São Tomé and Príncipe, Sierra Leone, Sudan, South- } \\
\text { Sudan, Tanzania, Timor-Leste, Uganda (OFD, 2013) }\end{array}$ \\
\hline Sweden & $\begin{array}{l}\text { Countries with which Sweden will conduct long-term development cooperation (12): } \\
\text { Africa: Burkina Faso, Ethiopia, Kenya, Mali, Mozambique, Rwanda, Tanzania, Uganda, } \\
\text { Zambia. Asia: Bangladesh, Cambodia. Latin America: Bolivia } \\
\text { Countries in conflict and/or post-conflict situations with which Sweden will conduct } \\
\text { development cooperation (12) Africa: Burundi, Democratic Republic of the Congo, } \\
\text { Liberia, Sierra Leone, Somalia, Sudan. Asia: Afghanistan, Timor-Leste. The Middle East: } \\
\text { Iraq, West Bank-Gaza. Latin America: Colombia, Guatemala. } \\
\text { Countries in Eastern Europe with which Sweden will conduct reform cooperation (9) } \\
\text { Europe: Albania, Bosnia and Herzegovina, Georgia, Kosovo, Former Yugoslav Republic of } \\
\text { Macedonia, Moldova, Serbia, Turkey, and Ukraine. } \\
\text { Countries to be phased out in which Sweden will conduct selective cooperation (7) Africa: } \\
\text { Botswana, Namibia, and South Africa. Asia: India, Indonesia, China, Viet Nam. } \\
\text { Countries to be phased out in which relations will be promoted in ways other than via } \\
\text { bilateral development cooperation (23): Africa: Angola, Côte d'Ivoire, Malawi, and } \\
\text { Nigeria. Asia: The Philippines, Laos, Mongolia, Pakistan, Sri Lanka, Thailand. Latin } \\
\text { America and the Caribbean: Chile, El Salvador, Haiti, Honduras, Nicaragua, Peru. Europe: } \\
\text { Armenia, Azerbaijan, Kyrgyzstan, Montenegro, Tajikistan, Russia. The Middle East: } \\
\text { Lebanon (MoFA, 2007) }\end{array}$ \\
\hline Denmark & $\begin{array}{l}\text { Africa: Ethiopia (Green Growth), Zimbabwe, Tanzania, Uganda, Mozambique, Ghana, } \\
\text { Burkina Faso, Mali, Niger, Somalia, Southern Sudan, Kenya, Zambia. } \\
\text { Asia and LAC: Pakistan, Burma, Indonesia, Palestinian Authority, Afghanistan, Nepal, } \\
\text { Bangladesh, Bolivia. } \\
\text { Denmark is strengthening its multilateral engagement. The cooperation needs to be } \\
\text { more efficient. This will be achieved by e.g. fewer and larger core contributions and the } \\
\text { establishment of innovation facilities. } \\
\text { The priorities for } 2014 \text { focus on four areas: } 1 \text {. Green growth, 2. Stability and protection, } \\
\text { 3. The strengthening of Denmark's multilateral engagement, 4. Development contracts } \\
\text { and budget support (The Danish Government, 2013) }\end{array}$ \\
\hline Norway & $\begin{array}{l}\text { Africa: Angola, Burundi, Ethiopia, Ghana, Kenya, Liberia, Libya, Madagascar, Malawi, } \\
\text { Mali, Mozambique, Somalia, South Africa, Sudan, Tanzania, The Democratic Republic of } \\
\text { Congo, Uganda, Zambia, Zimbabwe. } \\
\text { Asia to Oceania: Afghanistan, Bangladesh, China, India, Myanmar, Nepal, Pakistan, Sri } \\
\text { Lanka, Timor-Leste, Vietnam, }\end{array}$ \\
\hline
\end{tabular}




\begin{tabular}{|l|l|}
\hline Finland & $\begin{array}{l}\text { Europe: Bosnia Herzegovina, Kosovo, Serbia, } \\
\text { Latin America: Brazil, Haiti, Nicaragua, } \\
\text { Middle East: Palestine. (NORAD website, 2014) }\end{array}$ \\
\hline $\begin{array}{l}\text { Finland's long-term partner countries in the future are Ethiopia, Kenya, Mozambique, } \\
\text { Nepal, Tanzania and Zambia as well as Vietnam, a lower middle-income country, with } \\
\text { which Finland is gradually shifting to new cooperation modalities. } \\
\text { In the future Nicaragua will be supported mainly through cooperation with civil society } \\
\text { organisations. Finland is committed to long-term cooperation with Afghanistan and } \\
\text { carries out development cooperation with the Palestinian Territory and South Sudan. } \\
\text { Finland will increase its focus on multilateral organisations and development financing } \\
\text { institutions, and will work in these organisations in a more goal-oriented and strategic } \\
\text { manner (MoFA, 2012). } \\
\text { Finland has NAMAs planned with Bangladesh (brick sector) and Thailand (renewable } \\
\text { energy). }\end{array}$ \\
\hline $\begin{array}{l}\text { In some countries Nordic partners are physically located together and share diplomatic } \\
\text { premises e.g. Burma, Pakistan, Vietnam, and Bangladesh. (Ministers of Foreign Affairs } \\
\text { of the Nordic Countries, 2012) }\end{array}$ \\
\hline $\begin{array}{l}\text { Premises } \\
\text { Group }\end{array}$ & $\begin{array}{l}\text { Unlike Nordic cooperation around the environment, there is no official Nordic forum for } \\
\text { cooperation around International Development Assistance. }\end{array}$ \\
\hline
\end{tabular}

How such country partners and strategic priorities fit with fossil-fuel subsidy reform is not straightforward. Fossil-fuel subsidies are measured in different ways and have different impacts - sheer size matters for carbon reductions, but so does impact within national budgets. However, as described in Figure 2, given the IEA New Policies Scenario modelling, over half the reductions and phase-out of fossil-fuel subsidies must come from the Middle East, but with significant proportions from other regions (Africa 15\% and other non-OECD 13\%, assuming this includes India and Indonesia). This is in line with where current pre-tax fossil-fuel subsidies currently lie. However, where taxes and external costs are included subsidies are far larger across the globe, $40 \%$ being with developed countries (IMF, 2013). 
Figure 5: Pre-tax energy subsidies by region, 2011

\section{Total pre-tax subsidies $\$ 480$ billion}

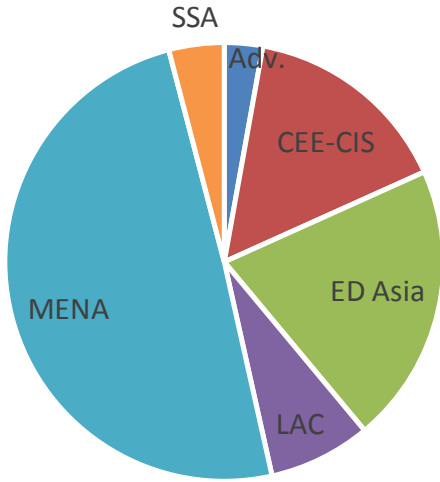

Source: Based on IMF (2013). Energy subsidies are concentrated in Middle East/North Africa (MENA), Central/Eastern Europe (CEE-CIS), and Emerging and Developing Asia (ED Asia). SSA = SubSaharan Africa, LAC= Latin America and Caribbean, Adv.= Advanced.

However, although size matters, the drain of fossil-fuel subsidies on government resources, especially low income and lower-middle income countries is a significant factor, even though the total contribution of such a subsidy on a global scale may be small. As explained in Section 3 fossil-fuel subsidies also impact on government budgets, deficits and ability to spend on other productive sectors of the economy such as education.

Countries with noticeable government subsidies, aimed at keeping petroleum products below market prices, include the following SubSaharan African countries: Cameroon, Nigeria, Ghana, Republic of Congo, Angola, and Ethiopia. In Asia such countries include Indonesia (around 14\%), Myanmar, Sri Lanka, Bangladesh, India, Malaysia, Brunei Darussalam, Bhutan, and Pakistan. Vietnam is also included as a possible partner country, with just over $3 \%$ of public expenditure subsidising petrol, coal and natural gas (see Figure 4). 
Figure 6: Emerging and Developing Asia, Pre-tax Subsidies for petroleum, 2011 (\% of government revenues)

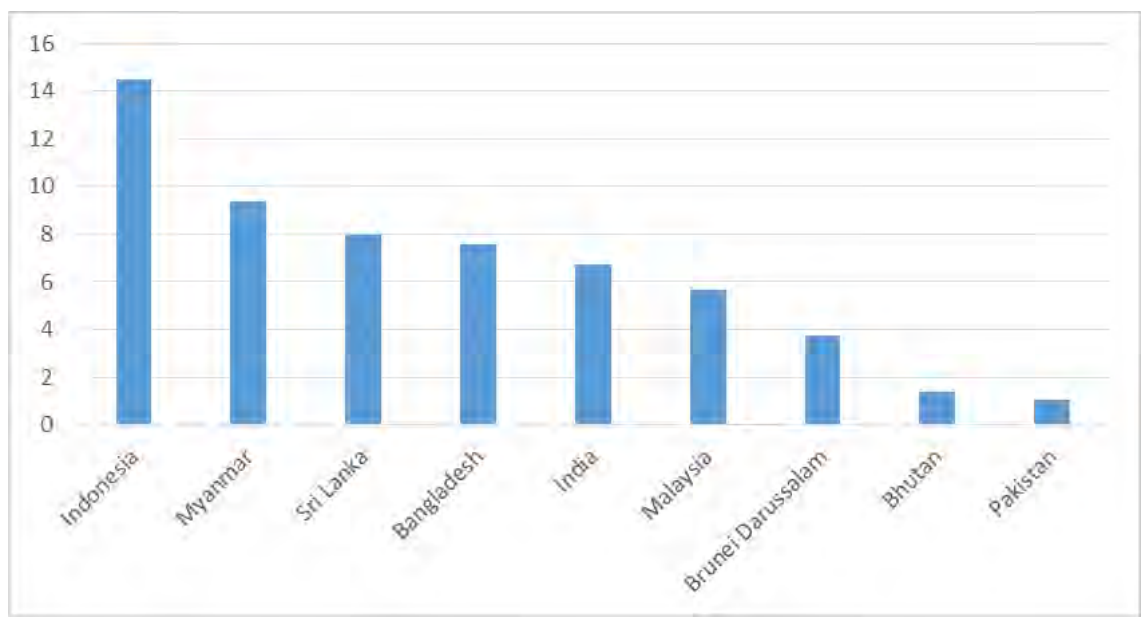

Source: IMF (2013). Note: Data for petroleum product subsidies on a pre-tax basis only. IMF figures for Vietnam are not available.

Some Central and Eastern Europe and Commonwealth Independent states (CEE-CIS) also display high levels of subsides to petroleum products such as Turkmenistan (over 30\%), but also the Kyrgyz Republic, Kazakhstan, Armenia, Georgia and Azerbaijan. Latin America and the Caribbean countries with significant subsidies include Venezuela (almost 16\%), Ecuador, Trinidad and Tobago, Bolivia, and Antigua and Barbuda. However, it is the Middle East and North Africa where pre-tax subsidies are striking. Egypt with subsidies of just over 30\% of government revenues on petroleum products alone, followed by most of MENA as illustrated in the figure below. 
Figure 7: MENA, Pre-tax Subsidies for Petroleum Products, 2011 (\% of government revenue)

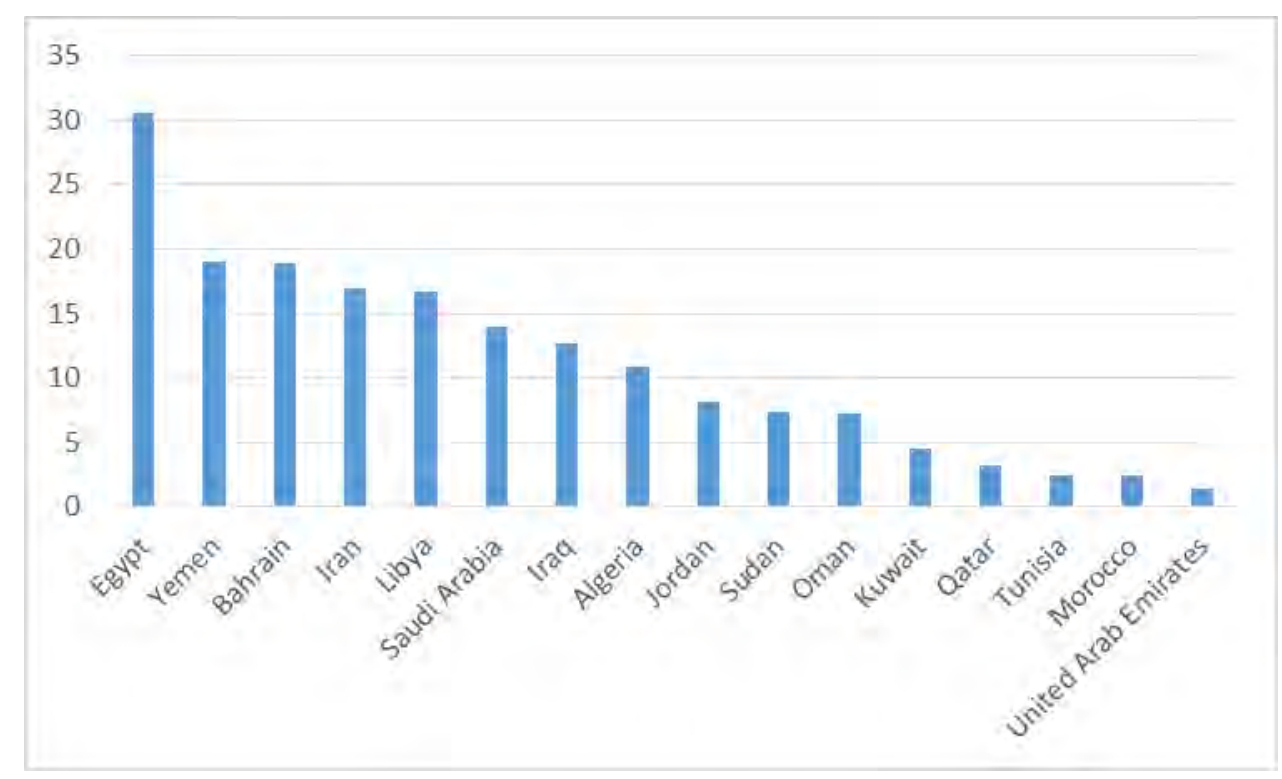

Source: IMF (2013) 


\section{Recommendations}

The NCM has provided the opportunity to discuss fossil-fuel subsidy reform widely across the Nordic countries and below are some recommendations stemming from the research. Some proposals fit the mandate of the NCM more than others. An important co-benefit of this research will be the opportunity to bring Nordic countries together to broadly discuss the issue of fossil-fuel subsidy reform in 2014 .

\section{Overall recommendations to NCM}

Fossil-fuel subsidies and their reform is an issue that touches on every area of the economy - but it is primarily a governmental fiscal issue, often closely tied with budget deficits and the political economy of countries. Reform is difficult and the approach that is taken matters. As this paper has outlined, fossil-fuel subsidy reform will have carbon mitigation benefits, resulting from short-term mitigation of national GHG emissions, but also due to 'getting the prices right' in order for renewables and energy efficiency to make economic sense in the longer term. Therefore, any of the recommendations outlined below could be pursued from an environmental perspective and all touch on development approaches. Yet, the GSI would propose that recommendations 7.1 and 7.2 may well link more closely with the mandate of NCM and for joint working on the issue across Nordic countries. 


\subsection{Supporting Reform with Carbon Mitigation Benefits}

GSI recommends that Nordic countries seek to support partner countries undertaking fossil-fuel subsidy reform through recognition or the purchase of carbon mitigation credits stemming from reform and through financial support to countries for low-carbon energy investment.

Nordic countries are seeking a low-carbon development path and must make changes nationally, but must also seek carbon emissions reductions elsewhere. Nordic countries have developed considerable expertise building two nationally appropriate mitigation actions (NAMAs) over the past three years, including funding from Sweden, NEFCO and NDF, within Vietnam (construction) and Peru (waste). Finland has NAMAs planned with Bangladesh (brick sector) and Thailand (renewable energy). This project would seek to build on this expertise and these institutions with another partner country. The potential to link with Norway's Energy+ partner countries should be explored. The potential for an energy sector NAMA with a partner country could build on both fossil-fuel subsidy reform (with the potential for some form of recognition of, or creditation for mitigation, either voluntarily or as certified emission reductions), and locking in some savings from reform towards new energy pathways with the potential for co-financing from Nordics. Potential partner countries could include: Bangladesh, Ethiopia, Kyrgyz Republic, and Myanmar (low-income) as well as Bhutan, Bolivia, Ghana, Indonesia, India, Pakistan, Sri Lanka, Vietnam and Sudan (lower-middleincome). ${ }^{3}$ The project could be designed either as a NAMA or separately as a voluntary carbon emissions mitigation action with positive carbon prices. Nordic countries also have strong expertise in geothermal technology that could be offered e.g. The Icelandic Development Corporation has recently started work with NDF to utilise geothermal technology in the Eastern Rift. The project could be attached to countries already planning reforms within the ESMAP programme as a co-benefit and/or an opportunity to ensure investment in low-carbon energy pathways following reform.

2014:

- Research and modelling of expected mitigation benefits based on previous reforms and the potential areas for secondary energy system impacts that could benefit from further investment.

- Two to three case studies of where countries undertaking fossil-fuel subsidy reform led to carbon reductions and were also able to make subsequent low-carbon investments.

- Ongoing discussions and building of project with a partner country.

${ }^{3}$ See the earlier mapping exercise for partner countries. 
- Understand and develop the process of applying for a NAMA, CERs or VERs. Assess an appropriate carbon price for reform.

- Understand, raise and build support for bringing fossil-fuel subsidy reform into the UNFCCC processes either via a NAMA or otherwise e.g. the potential to link work to ADP work stream 2 (Ad hoc Working Group on the Durban Platform for Enhanced Action pre-2020 ambition).

- Calculate costs and financing for low-carbon energy sector investment based on partner savings and donor co-financing.

- Establish a clear baseline prior to reforms.

- Organisation of development agreements and action plans between various parties.

Longer-term:

- Partner country undertakes specific fossil-fuel subsidy reforms.

- Measure impacts of reform: measuring, reporting, and verification.

- Pump-prime finance into low-carbon energy up front with matchfunding from Nordic partner governments, NDF, and NEFCO.

- Recognition or potential purchase of credits stemming from reform.

- Seek to develop an easy to use process that can be replicated with other partner countries.

\subsection{Energy Subsidy Management Network}

GSI sees the potential for an energy subsidy network of excellence that is demand driven, responding to the needs of countries to accelerate the pace and quality of fossil-fuel subsidy reform in both developed and developing countries, providing both information and technical assistance.

Whilst there has been progress on fossil-fuel subsidy reform in the last 10 years, a greater push could be made to eliminate fossil-fuel subsidies world-wide. Currently there are a limited number of experts based in IMF, IEA, the World Bank, the GSI and specific governments working on reform on a country-by-country basis. The GSI, as an initiative of an NGO, even with core Nordic support, has limitations in terms of scale, tackling subsidies on a project by project basis. However, if wider and more rapid reform is to take place and with full ownership of partner countries then the process of sharing information, training and enabling governments to measure, understand and deliver smoother reforms with appropriate flanking measures, themselves, could work with a model not dissimilar to the Extractive Industries Transparency Initiative (EITI). A focus on communications could be delivered. Specific case studies could aid governments in understanding the process of change and could include: Turkey, Ethiopia, Mexico and China, with an historical example from Norway. The EITI model, with support from Nordic governments, has developed a process that includes a standard and national 
cross-sector partnerships for transparency in the extractives sector. Such national processes, with associated coordinators, is a strong model for change, in that countries are guided by a standard but are in control of the process. A significant network of 'go-to' in-country experts could be developed based on the EITI model or in collaboration with ESMAP, EITI or another IO. The focus could be around communication with stakeholder groups on fossil-fuel subsidy reform including wider issues of pricing, social and environmental impacts, and energy investment. There is potentially appetite for such a network given the annual meeting GSI organises of fuel regulators from around the world. The focus of the Network would be governments: regulators, policy makers, civil servants from different departments, and Ministers. To enable governments to work through policy change and also communicate across stakeholder groups such as civil society and industry. Any such Network would require strong ownership and engagement from MENA and could be supported with virtual content.

2014:

- Map out what the Network could offer in terms of approaches to measurement, training, regional support, pricing advice and communication.

- Draft a business plan exploring collaboration with commonalities and/or collaboration with ESMAP and others.

- Identify potential countries to work with including strong ownership and partnership with MENA e.g. Yemen and Egypt, and lower middle income countries with high fossil-fuel subsidies.

- Engage cross-departmental governmental support and wider stakeholders with a few key initial countries.

- Develop training material packages including the bottom-up inventory approach to measurement and positive examples of what works well for countries undertaking reform.

Longer term:

- Scale-up fossil-fuel subsidy reform through the formalisation of a process by which countries can engage, measure and act.

- In-country point people enable countries to undergo smoother reform process with better understanding around communication, measurement, and management of impacts.

- Provide strong information and incentives around subsequent building in of tangible benefits to society of subsidy reform (e.g. lowcarbon energy or social expenditure). 


\subsection{Supporting Reform with Social Safety Nets}

GSI recommends that Nordic countries seek to support partner countries undertaking fossil-fuel subsidy reform through support for mitigation or flanking mechanisms around the process of reform and to build towards the development of targeted social safety nets aimed at the poor.

The impacts of fossil-fuel subsidy reform on the poor and on vulnerable groups should be minimised. Often subsidies were put in place to provide welfare assistance to low-income households; however, it has been found that fossil-fuel subsidies for the most part are an extremely ineffective way to target assistance to the poor. This project would aim to investigate the link between fossil-fuel subsidy reforms, those 'flanking' or 'mitigation' measures around reform and development of Social Safety Nets (SSNs). It can be argued that SSNs be a pre-requisite for reform but also that SSNs may develop independently of fossil-fuel subsidy reform via separate welfare policies and need not be explicitly linked. SSNs deliver non-contributory benefits, in-cash or in-kind for the poor and vulnerable. Examples of where fossil-fuel subsidy reform has been linked to one-off cash transfers include in Indonesia (2005 with 19.2 million households), Iran (2010 where $80 \%$ of the population applied) (GSI, 2013), and in the Philippines (2008, when 6.8 million households benefitted). In the case of Indonesia and Iran, SSNs did not emerge, in the Philippines better links to the national safety net scheme could now be made. There have been examples of flanking measures that seek to target the poor with cleaner fuels directly during the process of reform (Indonesia). Nordic countries have a history and expertise in SSNs and in gender equality, there could be an opportunity to not only reduce fossilfuel subsidies but also to reinforce or build safety nets and target cleaner fuels to poorer sections of the population and women at the same time.

2014:

- Research the link between fossil-fuel subsidy reforms, social 'flanking' or 'mitigation' measures (in-cash or in-kind), and the opportunity to build towards longer term SSNs. Produce two to three case studies of where countries undertaking reform managed change through the use of SSNs and other measures, and utilised savings from reform to the benefit of society.

- Explore the possibility for targeted and conditional SSNs to be linked directly to energy choices and policies important to gender e.g. cleaner cook stoves, cooking fuel, heating and lighting.

- Explore links to building long-term SSNs or tie-in with existing ones within the process of reform.

- Understand the fiscal cost of flanking measures involved in fossil-fuel subsidy reform for a number of countries with a focus on developing a partner country e.g. Bangladesh, Ethiopia, Kyrgyz Republic, and Myanmar (low-income) as well as Bhutan, Bolivia, Ghana, Indonesia, 
India, Pakistan, Sri Lanka, Vietnam and Sudan (lower-middleincome), ${ }^{4}$ some of which have emerging SSNs.

- Exploration and agreement with a partner country.

- Training with the partner country over the process of reform.

- Organisation of development agreements between various parties.

Longer term:

- Partner country undertakes specific fossil-fuel subsidy reform.

- Measure impacts of reform.

- Pump-prime finance into flanking measures up-front from Nordic countries and with match-funding from partner countries.

- Measuring, monitoring, and evaluation.

- Seek to develop an easy to use process that can be replicated with other partner countries.

\subsection{Supporting IFIs}

GSI recommends that Nordic countries seek to support and influence multi-lateral International Financial Institutions on the matter of fossil-fuel subsidy reform. Nordic countries can encourage IFIs to manage funds towards shaping a low-carbon future, including policies and programmes around fossil-fuel subsidy reform, ensuring that reforms are enacted in a way that manage social impacts as far as possible.

Nordic countries give a large proportion of IDA, and plan fewer and larger donations, towards multilaterals, implying that IFIs will have more resources going forward. Nordic donors must closely follow and shape the work of such institutions in line with Nordic thinking around green growth. Multilaterals make up a significant proportion of Nordic IDA, in some cases far larger than bilateral country to country assistance. IFIs have the scope to work broadly with many different countries at different stages of development and to tackle specific themes (e.g. health). The Nordic Development Fund has an energy subsidy policy, an approach which could be proposed to other IFIs. Similar approaches to this include the Equator Principles around environmental and social risk when investing in projects, and the International Finance Corporation (IFC) Performance Standards. In 2013 the World Bank Group, the European Bank for Reconstruction and Development, the U.S. Trade and Development Agency, and the European Investment Bank all announced new guidelines or positions to shift away from financing coal fired power 
plants overseas. Denmark is currently supporting the World Bank directly via ESMAP to support fossil-fuel subsidy reform. The GSI are being funded to provide a supporting role to this IFI in terms of advice around pricing, training with government officials, and communications work with wider stakeholder groups such as in Egypt. There have been concerns from some NGOs that reforms, post Arab Spring, from some IFIs have been focused purely on privatisation and public-private partnerships. Reform of fossil-fuel subsidies is sensitive and needs to be undertaken in a step-by-step approach. Reform requires communication work with all stakeholders, accompanying mechanisms that support the poor and vulnerable, tangible gains made for the energy sector or society as a whole, as well as managing and reducing public deficits. Supporting and working with IFIs to help governments deliver such change is important.

2014:

- Research on the success of, and potential use of, mitigation measures for reform, and potential support to low-carbon energy investments.

- Research on IFI polices towards fossil-fuel subsides and 'brown' energy flows.

- Targeted events and ongoing support to global and regional IFIs, particularly in regions with high subsidies (via IFIs: e.g. WB, EBRD, EID, IMF, ADB, AFDB, and IDB).

- Support to Nordic country IFI groupings, to raise the issue of fossilfuel subsidy reform.

- Development of a Friends learning group around the Danish funded ESMAP, IEA, and GSI reference group, designed to enable government practitioners to share information.

Longer-term:

- IFI investment policies in place, similar to NDF and geared towards supporting a low-carbon future and away from supporting fossil-fuel subsidies.

- IFI programmes in place to support reform within countries, potentially with co-financing to IFIs from Nordics to support countries who undertake fossil-fuel subsidy reform, based on policy and programme commitments, support for flanking or mitigation measures, and gains made for the energy sector and society as a whole.

- Wider influence, through private investment banks taking up similar positions and due to co-financing arrangements with IFIs. 


\section{References}

Arze Del Granado, J., Coady, C., and Gillingham, R., (2010): “The Unequal Benefits of Fuel Subsidies: A Review of Evidence for Developing Countries". IMF.

Bruvoll, A., Magne Skjelvik, J. and Vennem, H., (2011): “Reforming Environmentally Harmful Subsidies, how to counteract distributional impacts."

Burniaux, J.-M., Chanteau, J., Dellink, R., Duval, R. and Jamet, S. (2009): “The economics of climate change."

The Danish Government (2013): "Priorities for the Danish Development Cooperation, Overview of the Danish Corporation budget 2014-2017."

Duflo, E., Greenstone, M., and Hanna, R. (2008): "Indoor Air Pollution and Respiratory Health in Rural Orissa." Center for Energy and Environmental Policy research, MIT.

Gerasimchuk, I., (2013): "Mapping Options for a Voluntary Peer Review of FossilFuel Subsidy Reform within the G-20.” The Global Subsidies Initiative.

The Global Subsidies Initiative (2010): “Untold Billions Fossil-Fuel Subsidies, Their Impacts and the Path to Reform. A Summary of Key Findings"

The Global Subsidies Initiative (2013): Beaton, C., Gerasimchuk, I., Laan, T., Lang, K., Vis-Dunbar, D., and Wooders, P., "A Guidebook to Fossil-fuel Subsidy Reform for Policy Makers in Southeast Asia."

IEA (2011): “World Energy Outlook 2011.”Paris: OECD/IEA.

IEA (2013): "Redrawing the Energy Climate Map World Energy Outlook Special Report."

IMF (2013): "Energy Subsidy Reform: Lessons and Implications."

Kingdom of Denmark, Republic of Finland, Republic of Iceland, Kingdom of Norway, Kingdom of Sweden, and the United States of America, 04 September 2013 "Joint Statement."

Kishore, A., (2013): "India in Transition, Empowering Women to Reduce Indoor Air Pollution in India."

Koplow, D. (2009): "Measuring energy subsidies using the price-gap approach: What does it leave out?" Winnipeg: International Institute for Sustainable Development.

Ministers for Foreign Affairs of the Nordic Countries, (2012): "Declaration by the Ministers for Foreign Affairs of the Nordic Countries, Nordic Diplomatic Cooperation", Helsinki.

Ministry of Foreign Affairs, Finland (2012) "Finland's development policy programme 2012, Government decision-in-principle 16 February 2012"

Ministry of Foreign Affairs, Sweden (2007): "Focused bilateral development cooperation."

Nakhooda, S., Fransen, T., Kuramochi, T., Caravani, A., Prizzon, A., Shimizu, N., Tilley, H., Halimanjaya, A., Welham, B. (2013). "Mobilising International Climate Finance: Lessons from the Fast-Start Finance Period."

Naturvårdsverket (2012) "Potentiellt miljöskadliga subventioner Förstudie från 2005 - uppdaterad 2011"

The Nordic Development Fund (2010): “Nordic Development Fund Position Paper on Energy Subsidies."

The Nordic Council of Ministers (2011): "The Nordic Region - leading in green growth Report by the Nordic prime ministers' Working Group for Green Growth"

The Nordic Council of Ministers (2012): "Nordic Environmental Action Plan 20132018." 
Norad (2014): "Norway in the world" http://www.norad.no/en/countries

OECD (2011): "An inventory of estimated budgetary support and tax-exemptions for fossil-fuels."

OFD (2013): "Introduction to OFD"

Whitley, S., (2013): "Time to change the game Fossil-fuel subsidies and climate."

The World Bank (2014a): "Energy the Facts." www.worldbank.org

The World Bank (2014b): "Social Protection in Africa." www.worldbank.org

WHO (2009): "Indoor Air Pollution and Health Factsheet 292 2011."

WHO (2014): 2011 data from

http://apps.who.int/nha/database/DataExplorer.aspx?ws=0\&d=1 


\title{
9. Acronyms
}

\author{
APEC Asia Pacific Economic Cooperation \\ BRICs Brazil, Russia, India, China \\ CEE-CIS Central and Eastern Europe and Commonwealth of Independent States \\ CER Certified Emission Reduction \\ EITI Extractive Industries Transparency Initiative \\ ESMAP Energy Sector Management Assistance Program \\ FFSR fossil-fuel subsidy reform \\ GHG greenhouse gas \\ GSI The Global Subsidies Initiative of IISD \\ IDA International Development Assistance \\ IEA International Energy Agency \\ IFC International Finance Corporation \\ IFIs International Finance Institutions \\ IISD International Institute for Sustainable Development \\ IO International Organisation \\ LAC Latin American and Caribbean \\ LDCs Least Developed Countries \\ LPG Liquefied Petroleum Gas \\ MENA Middle East and North Africa \\ NAMA Nationally Appropriate Mitigation Action \\ NCF Nordic Climate Facility \\ NCM The Nordic Council of Ministers \\ NDF Nordic Development Fund \\ NEFCO Nordic Environment Finance Cooperation \\ NGO Non-governmental Organisation \\ NOAK The Nordic working group for global climate negotiations \\ NPI Nordic Partnership Initiative on Up-scaled Mitigation Action \\ OECD Organisation for Economic Co-operation and Development \\ OFD Oil for Development \\ REDD+ Reducing Emissions from Deforestation and Forest Degradation plus \\ SE4ALL Sustainable Energy for All \\ SEPA Naturvårdsverket (The Swedish Environmental Protection Agency) \\ SSA Sub-Saharan Africa \\ SSNs Social Safety Nets \\ UNFCCC United Nations Framework Convention on Climate Change \\ VER Voluntary Emission Reduction \\ WB The World Bank Group
}




\section{Appendices}

\subsection{List of people consulted}

The GSI would like to thank the NCM, all those listed below who met with us as well as support staff who helped set meetings up. This project has enabled Nordic officials, GSI and others to discuss and think about how Nordics are and can support efforts towards fossil fuel subsidy reform. Any omissions or mistakes are the authors own.

- Tanja Larsen Danish Ministry of Climate, Energy and Building (KEBMIN)

- Nikolaj Lomholt Svensson Danish Ministry of Climate, Energy and Building (KEBMIN)

- Kaare Barslev, Head of Department, Ministry of Foreign Affairs of Denmark

- Jakob Rogild Jakobsen, Chief Adviser, Department for Green Growth, Danish Foreign Ministry

- Mr Steen Lohmann Poulsen Ministry for Interior and Economic Affairs, Denmark

- Charlotte Kirkegaard (Danish gender consultant)

- Anna Maria Hill Mikkelsen, Nordic Council of Ministers

- Michael Funch, Nordic Council of Ministers

- Páll Tómas Finnsson, writer

- Ms. Tove Zetterström Goldmann, Policy Specialist Climate Change, Swedish International Development Cooperation Agency (SIDA)

- Fredrik Hannerz, Head of Section, Climate Division, Ministry of the Environment, Sweden

- Sara Almqvist, Swedish Environmental Protection Agency and NOAK

- Katrin Zimmer, Environmental Economist, International Cooperation Unit, Policy Development department, Swedish Environmental Protection Agency

- Ping Höjding, Programme Manager, International Cooperation, Swedish Environmental Protection Agency

- Kerstin Grönman, Swedish Ministry of Environment

- Arvid Loken, Senior Innovation Adviser, Nordic Innovation

- Jonas Ivarsson, Senior Innovation Adviser, Nordic Innovation

- Benjamin Smith, Senior Adviser, Nordic Energy Research

- Leiv Lunde, Director, Fridtjof Nansens Institute (Board Member IISD)

- Aksel Hillestad, Higher Executive Officer, Norwegian Ministry of the Environment 
- Gard Lindseth, Norwegian Ministry of the Environment

- Sveinung Kvalø, Senior Adviser Norwegian Ministry of the Environment

- Even Stormoen, Senior Adviser, Norwegian Ministry of Foreign Affairs

- Terje Kronen, Ministry of Environment/Ministry of Foreign Affairs, Energy +

- Heidi Sandvand Hegertun, Adviser, NORAD, Oil for Development

- Kjerstin Adreasen, Administrator, Extractive Industries Transparency Initiative (EITI)

- Jonas Moberg, Head of Secretariat, EITI

- Eddie Rich, Deputy Head and Regional Director for Africa and the Middle East, EITI

- Professor Richard Klein, Senior Research Fellow, Stockholm Environment Institute

- Pasi Hellman, Managing Director, Nordic Development Fund (NDF) (via Skype)

- Hannu Eerola, Country Program Manager, NDF (via Skype)

- Timo Lappalainen, Executive Director, KEPA, Finland

- Henri Purje, Advocacy and Policy Officer, KEPA, Finland

- Outi Honkatukia, Senior Adviser, Economics Department, Ministry of Finance, Finland

- Jatta Jämsén, Counsellor, Climate Change, International Environmental Policy/Department for Development Policy, Ministry for Foreign Affairs of Finland

- Sari Alander, Programme Officer, Financing for Sustainable Development, Department for Development Policy, Ministry for Foreign Affairs of Finland

- Anu Maria Hassinen, Energy Advisor, Department for Development Policy, Ministry for Foreign Affairs of Finland

- Johanna Pietikäinen, Administrator, International Environment Policy, Ministry for Foreign Affairs of Finland

- Pauli Mäkelä, Ambassador, Department for External Economic Relations, Ministry for Foreign Affairs of Finland

- Martti Hetemäki, Permanent State Secretary, Ministry of Finance, Finland

- Matti Numelin, Senior Environmental Adviser, Department for Development Policy, Ministry for Foreign Affairs of Finland

- Riikka Laatu, Deputy Director General, Department for Development Policy, Ministry for Foreign Affairs of Finland

- Harri Laurikka, Chief negotiator for climate change, Environmental Protection Department/ Climate Change, Ministry of the Environment, Finland

- Ann-Britt Ylinen, Senior International Adviser, Unit for International and EU Affairs, Ministry of the Environment 
- Outi Leskelä, Planning Officer, Ministry of the Environment / Environmental Protection Department

- Pasi Rinne, Chairman of Gaia Group, Gaia

- Mikko Halonen, Leading Consultant, Gaia

- Ash Sharma, Vice President, Head of Department, Carbon Finance and Funds, Nordic Environment Finance Corporation (NEFCO) (via telephone)

- Danfríður Skarphéðinsdóttir, Head of Division, Ministry for the Environment and Natural Resources, Department of Oceans, Water and Climate, Iceland (via e-mail)

Those involved with the production of this report at the GSI: Laura Merrill, Damon Vis-Dunbar, and Peter Wooders, the Global Subsidies Initiative, International Institute for Sustainable Development.

\subsection{List of questions posed}

- Which countries or regions are supported in efforts towards fossilfuel subsidy reform?

- Which multilateral organizations and institutions have been supported with regard to subsidy reform from Nordics?

- Which existing Nordic government programmes and strategies have a potential fit with fossil-fuel subsidy reform?

- What specific areas could be more fully developed and understood to enable successful fossil-fuel subsidy reform, and where Nordic countries could add value, with regard to management of pricing, impacts, policy and communications?

- What opportunities do Nordics see for inclusion of fossil-fuel subsidy reforms within UNFCCC and/or Nationally Appropriate Mitigation Actions? And with regard to leadership around reform in global and regional arenas such as within the WTO, regional trade blocs and groupings?

- What big picture view do Nordics hold with regard to the potential for change from fossil-fuel subsidy reform and how could they make this happen?

- Which particular regions or countries do Nordics want to concentrate efforts within for reform? Middle and high income countries, effort with BRICS, MENA? Support to low income countries? 


\subsection{Country Subsidies}

The tables below illustrate those countries with pre-tax subsidies for petroleum products (only) greater than $1 \%$ of government revenues for 2011. The data used is conservative (a pre-tax figure and does not include other fossil-fuel subsidies such as natural gas and coal, where data is very often lacking, nor does it include large subsidies targeted at the electricity sector). Charts are organised by region and figures are taken from the IMF (2013).

Figure 8: Sub-Saharan Africa, Petrol subsidies \% government revenues

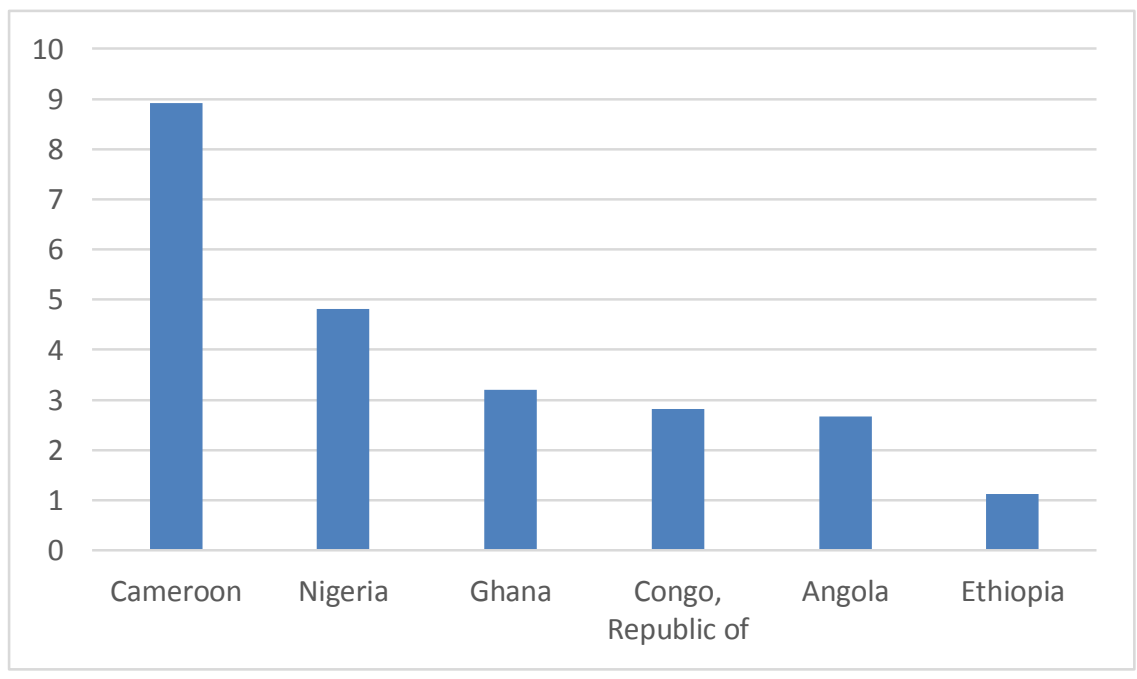

Figure 9: CEE-CI, Petrol subsidies \% government revenues

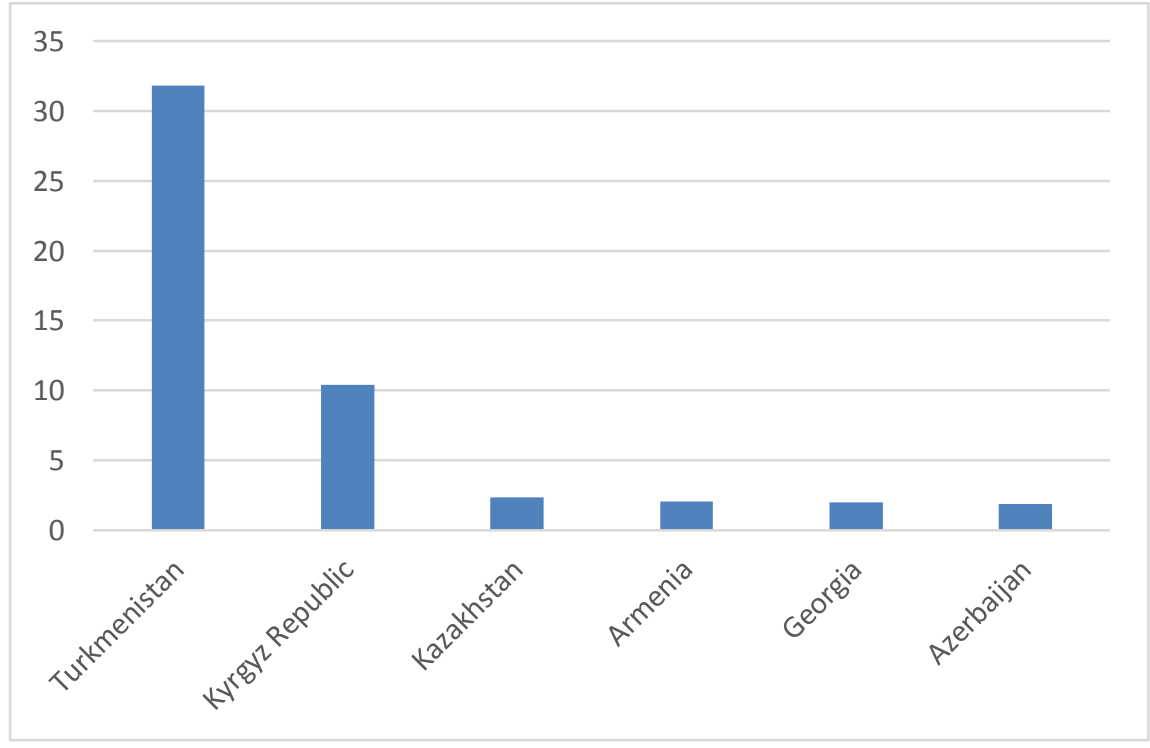


Figure 10: LAC, Petrol subsidies \% government revenues

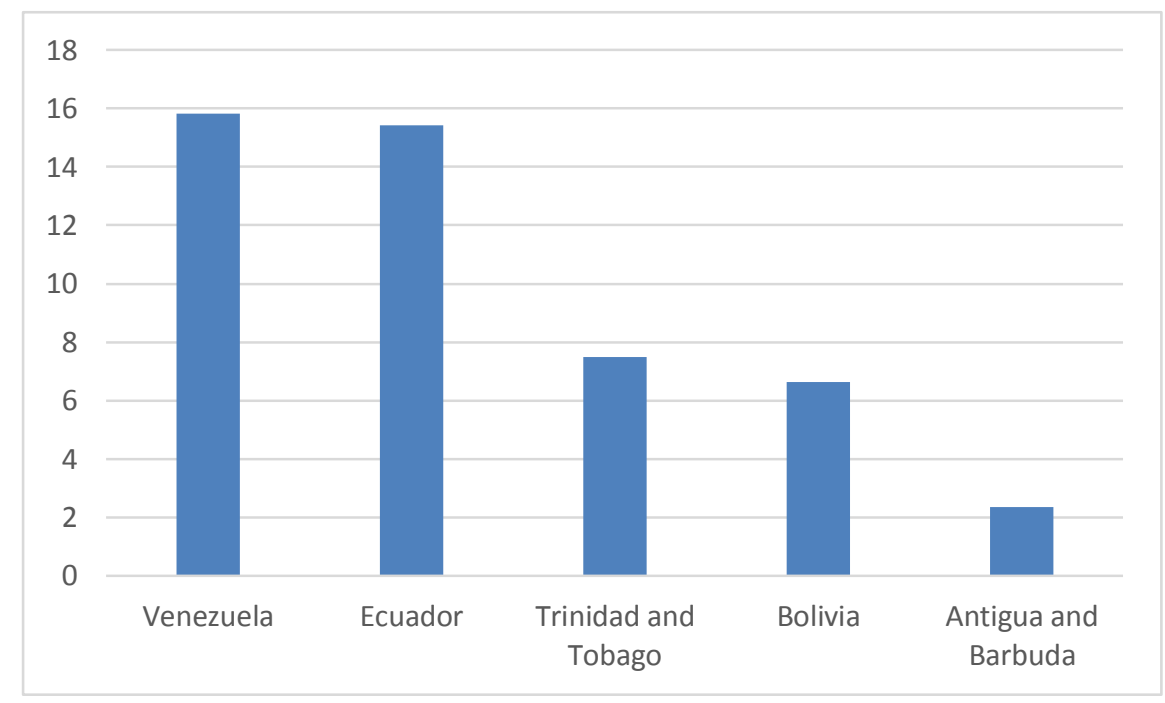

